This item was submitted to Loughborough's Research Repository by the author.

Items in Figshare are protected by copyright, with all rights reserved, unless otherwise indicated.

\title{
Glucose diffusion in tissue engineering membranes and scaffolds
}

PLEASE CITE THE PUBLISHED VERSION

http://dx.doi.org/10.1515/revce-2015-0021

PUBLISHER

De Gruyter

VERSION

VoR (Version of Record)

\section{PUBLISHER STATEMENT}

This work is made available according to the conditions of the Creative Commons Attribution-NonCommercialNoDerivatives 4.0 International (CC BY-NC-ND 4.0) licence. Full details of this licence are available at: https://creativecommons.org/licenses/by-nc-nd/4.0/

\section{LICENCE}

CC BY-NC-ND 4.0

\section{REPOSITORY RECORD}

Suhaimi, Hazwani, and Diganta Das. 2015. "Glucose Diffusion in Tissue Engineering Membranes and Scaffolds". figshare. https://hdl.handle.net/2134/18781. 
Hazwani Suhaimi and Diganta Bhusan Das*

\section{Glucose diffusion in tissue engineering membranes and scaffolds}

DOI 10.1515/revce-2015-0021

Received April 8, 2015; accepted August 28, 2015; previously published online June 7, 2016

\begin{abstract}
Tissue engineering has evolved into an exciting area of research due to its potential in regenerative medicine. The shortage of organ donors as well as incompatibility between patient and donor pose an alarming concern. This has resulted in an interest in regenerative therapy where the importance of understanding the transport properties of critical nutrients such as glucose in numerous tissue engineering membranes and scaffolds is crucial. This is due to its dependency on successful tissue growth as a measure of potential cure for health issues that cannot be healed using traditional medical treatments. In this regard, the diffusion of glucose in membranes and scaffolds that act as templates to support cell growth must be well grasped. Keeping this in mind, this review paper aims to discuss the glucose diffusivity of these materials. The paper reviews four interconnected issues, namely, (i) the glucose diffusion in tissue engineering materials, (ii) porosity and tortuosity of these materials, (iii) the relationship between microstructure of the material and diffusion, and (iv) estimation of glucose diffusivities in liquids, which determine the effective diffusivities in the porous membranes or scaffolds. It is anticipated that the review paper would help improve the understanding of the transport properties of glucose in membranes and scaffolds used in tissue engineering applications.
\end{abstract}

Keywords: diffusion; glucose; membrane; scaffold; tissue engineering.

\section{Introduction}

Organ shortage and failures due to accidental and illness incidences have been a concern in almost every part of the world. Organ transplantation has been a common practice

*Corresponding author: Diganta Bhusan Das, Department of Chemical Engineering, Loughborough University, Leicestershire LE11 3TU, UK, e-mail: D.B.Das@lboro.ac.uk

Hazwani Suhaimi: Department of Chemical Engineering, Loughborough University, Leicestershire LE11 3TU, UK in clinical settings and has been reported to be successful as early as the 1960s (Couch et al. 1966). Although it has been perceived to be successful, it also has its limitations, e.g. long patient waiting time and death of organ donors (Liu et al. 2013, Guo and Ma 2014). To overcome these limitations, engineers, biologists, chemists, and material experts have come together to create the tissue engineering (TE) approach as an alternative to organ transplantation, which provides a cost-effective treatment, resulting in improved health care and quality of lives of the patients. TE is therefore defined as a multidisciplinary field that helps to repair, replace, and restore the original functions of damaged tissues (Langer and Vacanti 1993, Liu et al. 2013). A simple illustration of TE principles is shown in Figure 1. As the figure shows, TE approach aims to mimic the in vivo environment to help in cell proliferation and differentiation into tissues and consequently tissue regeneration (Tabata 2014). In brief, living cells are harvested from a patient's body of relative excess followed by expansion of these cells in vitro. The cells are then loaded on tissue engineered scaffolds, which act as a template for cell growth in a process known as cell seeding. The cells are grown with the supply of nutrients (e.g. glucose and oxygen) and monitored for its physiologically relevant standards for bone TE (BTE) in terms of cell-cell and cell-matrix interactions as well as possessing the nanostructural and chemical extracellular matrices (ECMs) (Zhu et al. 2015) as found in the native ECM of the body. Surgical implantations into the host body are carried out, and finally, the functionality of the regenerated tissue is observed in vivo.

Due to its numerous successes, TE has become the leading choice in the field of regenerative medicine (Khaled et al. 2011). The main goal of TE is to produce an alternative that can overcome the limitations of traditional treatments and possess a good potential to eventually form an "artificial" organ that resembles the original organ in terms of function and ability. Furthermore, it is envisaged that a TE approach presents a permanent cure without the need for follow-up therapies (Langer and Vacanti 1993, Patrick et al. 1998). For example, BTE, which has been reported since the early 1980s (Amini et al. 2012), has become a substitute for bone grafting.

TE researchers have shown the possibility of growing artificial tissues both in vitro and in vivo, e.g. bone, 


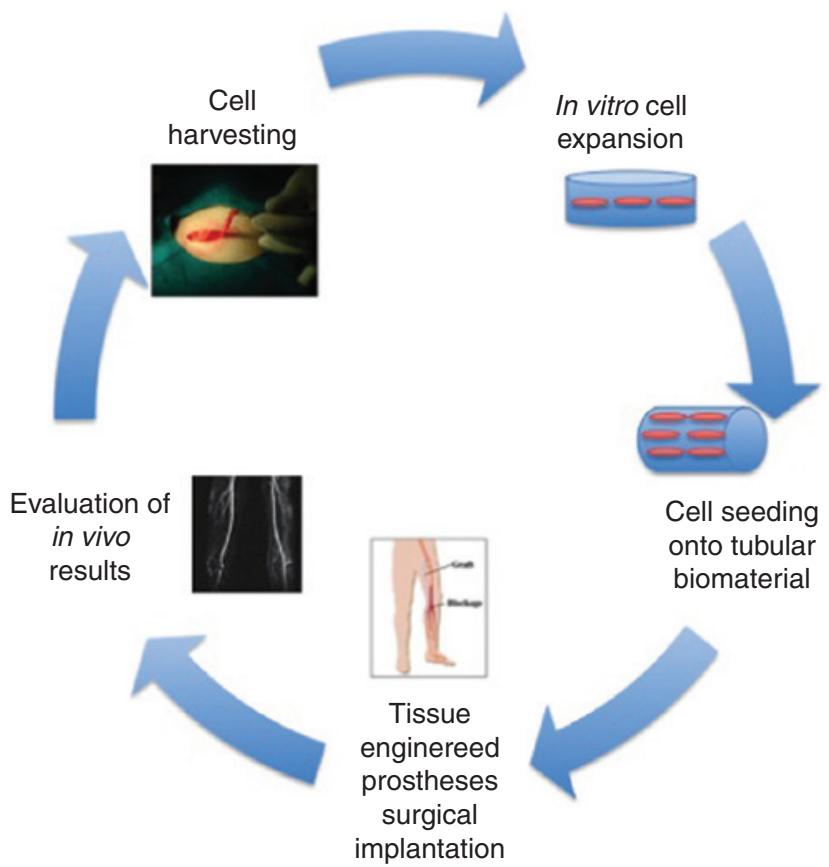

Figure 1: Basic principles of TE (Vindigni et al. 2011; reproduced with permission of InTech publisher under CC BY-NC-SA 3.0 license. Available from http://dx.doi.org/10.5772/24899).

cartilage, tendon, and blood vessel tissues (L'Heureux et al. 2007, Schulz et al. 2008, Abousleiman et al. 2009, Grayson et al. 2010, Kimelman-Bleich et al. 2011, Omae et al. 2012). However, it is proven difficult to grow tissues in vitro than in vivo due to the absence of a natural capillary network that supplies nutrients (e.g. glucose) and removes waste products (e.g. lactic acid) as well as the inaccessibility of a controlled environment during cell cultivation (Li et al. 2014). Hence, the idea of growing artificial tissues in bioreactors has been introduced.

Bioreactors are defined as a growth kit that helps to monitor and control necessary conditions for cell growth (e.g. pH, pressure, temperature, nutrient supply, and removal of waste product) as well as synchronising both biological and biochemical processes involved in cell culture (Gardel et al. 2014). There have been several reported studies that show the development of these bioreactors to grow 3D tissues, such as spinner flasks (Page et al. 2013), rotating vessels (Nishi et al. 2013, Chao and Das 2015), and flow perfusion systems (Baptista et al. 2013). Although these bioreactors satisfy tissue engineers to the extent of improved tissue growth, they may still not able to sustain the cell culture environments (Li et al. 2014). One of the reasons is due to the limited nutrient diffusion in the scaffold and membrane in the bioreactor.

An example of a bioreactor where the issues with limited mass transfer has largely been overcome is hollow fibre membrane bioreactors (HFMBs) (Abdullah et al. 2006, Das and Jones 2006, Ye et al. 2006, Das 2007, De Napoli et al. 2011, Mohebbi-Kalhori et al. 2012). The presence of a network of hollow fibre membranes in the bioreactor allows nutrients (e.g. glucose) to diffuse into the scaffolding matrix and membrane and remove waste products produced by the cells (e.g. lactic acid) (Ye et al. 2006). This therefore allows a nutrient circulation system identical to that in the natural tissue to be generated, consequently creating better mass transfer behaviour and allowing high nutrient concentration to be maintained in HFMBs (Abdullah and Das 2007, Pearson et al. 2013, De Napoli et al. 2014, Misener et al. 2014).

Mass transfer behaviour in TE bioreactors is generally governed by one or more than one of the following processes, namely, convection, diffusion, and reaction. Convection refers to the coupled mass transport due to fluid flow (i.e. advection) and diffusive transport, while diffusion refers to the transport of molecules due to concentration gradient alone. Reaction is illustrated by the formation of a new product (for e.g. C) as a result of a chemical or metabolic reaction. An example of a bioreactor that involves all three processes is the HFMBs. Figure 2 shows a schematic drawing that reveals the three main sections, mainly, the extracapillary space (ECS), which can be referred as scaffold; membrane; and lumen. In the figure, $R_{1}$ refers to the fibre lumen radius, while $R_{2}$ illustrates $R_{1}$ and the thickness of the membrane wall. $R_{3}$ represents $R_{2}$ and the ECS thickness, while $L$ refers to the fibre length. As for $A_{1}, A_{2}$, and $A_{3}$, they refer to the lumen, membrane wall, and half of the ECS, respectively.

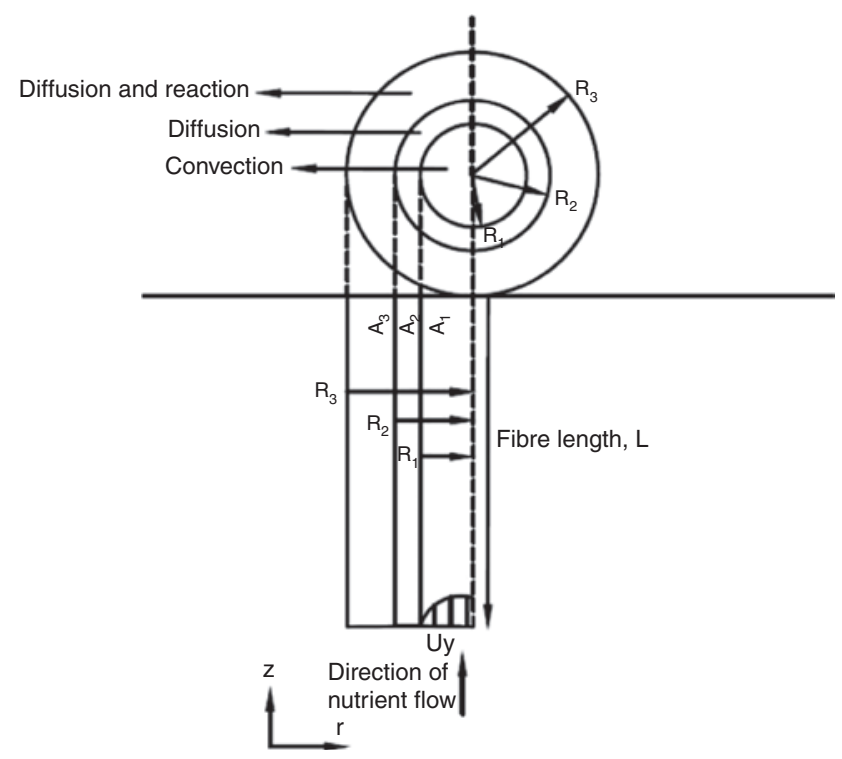

Figure 2: Schematic diagram showing a single hollow fibre. 
According to Ye et al. (2006), Das (2007), and Abdullah et al. (2009), the transport of a solute in the fibre lumen region is governed by advection and diffusion, but the advective process dominates the diffusive process. In the membrane region, solute transport is governed by diffusion only. In the ECS, the solute transport is governed by reaction and diffusion processes; however, reaction process dominates the diffusive transport.

A surge of interest has been observed in trying to understand the mass transfer behaviour in TE bioreactors (Khaled and Vafai 2003, Khanafer and Vafai 2006, Wang et al. 2009, Podichetty et al. 2014). In the last two decades, the use of membranes and scaffolds as a synthetic ECM for TE studies has also gained popularity, which is evidenced from the increasing number of publications (Figure 3A and $\mathrm{B})$. The TE discipline has grown remarkably and the significance of understanding the importance of TE applications is demonstrated by the fact that the number of patients waiting for transplants is almost doubled to those who actually received the transplants, as shown in Figure
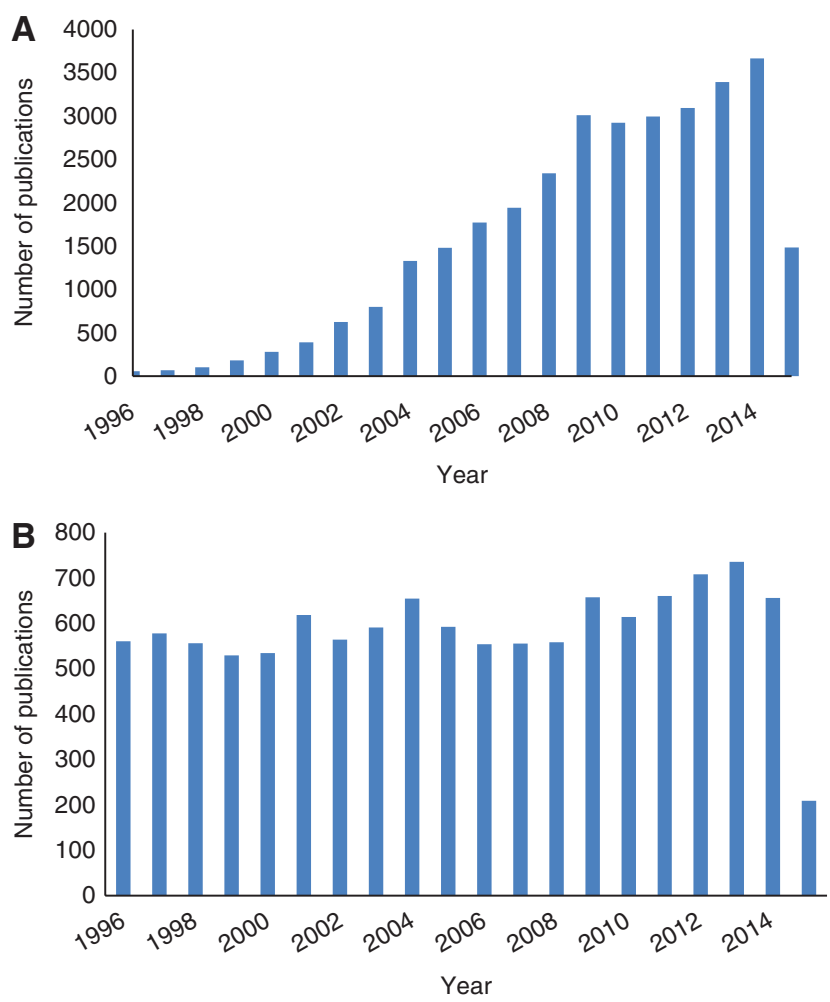

Figure 3: (A) Overview of the number of papers published with regard to TE membranes and scaffolds during the last 18 years (key words: membranes and scaffolds for TE; search engine: www. scopus.com). (B) Overview of the number of papers published with regard to glucose transport in TE materials during the last 18 years (key words: glucose transport in TE membranes and scaffolds, tissue bioreactors; search engine: www.scopus.com).
4 (Regional data, United Network for Organ Sharing). This trend continues, where only 27,036 people received transplants, while 77,917 people were on the waiting list, from January 2014 to November 2014.

To combat this challenge, numerous studies have been conducted to enhance the understanding of the field of regenerative medicine; more specifically, in the field of TE and research has already indicated the necessity of a bioreactor system, which is essential for a controlled environment during cell cultivation (Li et al. 2014).

One of the key features of most TE bioreactors is the use of membrane and scaffold, which acts as a support for cells to grow into new tissues before being implanted into the host tissue. One of the important criteria of this support system is the highly porous structure for ease of nutrient diffusion, particularly glucose, to produce a 3D structure of new tissues (Deans et al. 2012, Florczyk et al. 2013, Guan et al. 2013). Table 1 shows some typical examples of morphological structures of membrane/scaffold materials that can have an effect on the nutrient diffusion for cell growth. These will be discussed later in the paper. Please note that the materials presented in Table 1 might not be necessarily used in TE applications. The objective here is to show the variation of morphological structure of various kinds of membranes/scaffolds, which can affect the solute diffusivity.

Since solute diffusion is dependent on the material morphology, there is not a particular membrane structure for better glucose diffusion; however, based from extensive literature studies, hollow fibre membranes seem to illustrate a promising indication for enhanced glucose

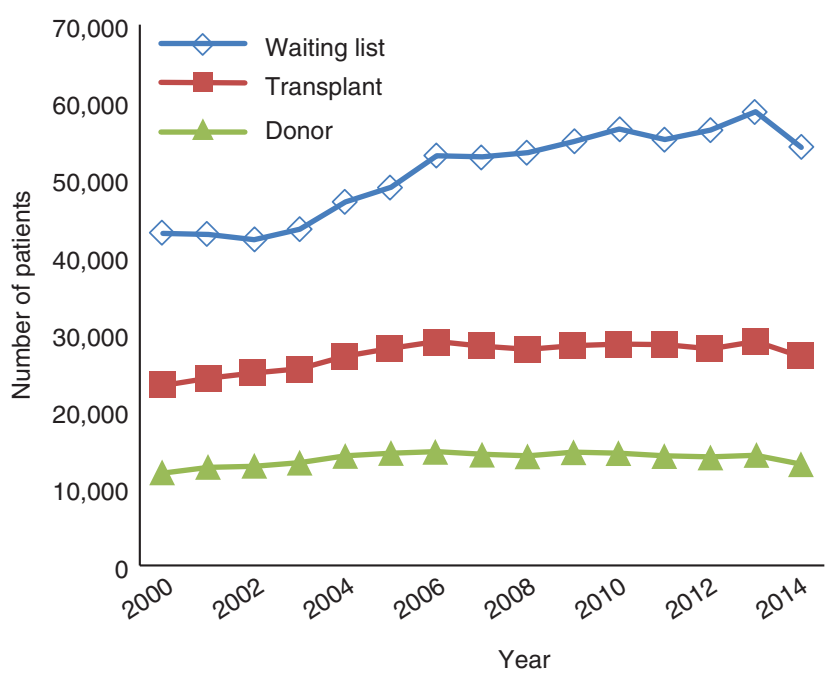

Figure 4: Overview of the number of patients on the waiting list, received transplants, and the donor statistics from 2000 to 2014 (data collected from www.unos.org). 
Table 1: Some examples of membranes showing different morphological structures.

\begin{tabular}{|c|c|c|}
\hline Membrane type & Schematic of cross-section & References \\
\hline $\begin{array}{l}\text { Poly(trimethylene } \\
\text { terephthalate) (PTT) }\end{array}$ & & Li et al. (2013), Xue et al. (2010) \\
\hline $\begin{array}{l}\text { Thin film composite } \\
\text { (TFC) membrane }\end{array}$ & & Han (2013) \\
\hline PSf membrane & & Crock et al. (2013), Zhao et al. (2011) \\
\hline $\begin{array}{l}\text { Poly(vinylidene fluoride) } \\
\text { (PVDF) hollow fibre } \\
\text { membrane }\end{array}$ & & $\begin{array}{l}\text { Sukitpaneenit and Chung (2009), Zhang } \\
\text { et al. (2013a,b), Liu et al. (2009) }\end{array}$ \\
\hline PVDF membrane & & Lin et al. (2002), Li et al. (2012) \\
\hline $\begin{array}{l}\text { Polyethersulfone (PES) } \\
\text { membrane }\end{array}$ & & $\begin{array}{l}\text { Madaeni and Bakhtiari (2012), Rahimpour } \\
\text { et al. (2012), Daraei et al. (2013) }\end{array}$ \\
\hline $\begin{array}{l}\text { Poly(amide-imide) (PAI) } \\
\text { hollow fibre membrane }\end{array}$ & & Setiawan et al. (2011), Zhang et al. (2011) \\
\hline $\begin{array}{l}\text { Ceramic asymmetric } \\
\text { membrane }\end{array}$ & & $\begin{array}{l}\text { Kim and der Bruggen (2010), DeFriend } \\
\text { et al. (2003), Tsuru et al. (2001) }\end{array}$ \\
\hline $\begin{array}{l}\text { Cellulose acetate blend } \\
\text { membrane }\end{array}$ & & $\begin{array}{l}\text { Han et al. (2013), Mohammadi and } \\
\text { Saljoughi (2009) }\end{array}$ \\
\hline
\end{tabular}

Different morphological structures of these materials affect the glucose diffusivity though the materials. 
delivery into the cells (Abdullah and Das 2007, Bettahalli et al. 2011a,b, Diban and Stamatialis 2014, Wung et al. 2014). Hollow fibre membranes have a large surface areato-volume ratio, therefore allowing a relatively high flow rate of culture medium containing glucose to be maintained. The basic building blocks of any membrane material are usually non-periodic and display heterogeneity in nature as they vary within the same material, or from one material to another, which defines the non-linear and non-monotonic relationship between membrane material and glucose transport. If the membrane/scaffold material is less tortuous and more porous, the glucose diffusion is smoother than one in a more tortuous structure, which would limit the glucose diffusion. However, there is a possibility that the glucose diffusion may be enhanced especially in hydrophilic materials, but the results of Suhaimi et al. (2015b) indicated no difference between hydrophobic and hydrophilic materials with regard to diffusivity data. In this work, they investigated the glucose diffusion in both hydrophobic and hydrophilic materials, and their results showed that instead of a difference in diffusivity date due to hydrophobic and hydrophilic nature, the difference in the morphological structure of the materials was deduced as the primary factor for different diffusivity data presented in their work.

In a TE process, the supporting template for cell growth plays a crucial role in cell attachment, differentiation, and proliferation (Guo and Ma 2014). Researchers have identified several important characteristics which scaffolds must have, e.g. (1) biocompatibility and biodegradability, (2) high porosity and connectivity of pores for diffusion, (3) appropriate surface chemistry and surface topography for cellular interaction, (4) good mechanical properties for regeneration, and (5) low/no adverse response (Hutmacher 2001, Yang et al. 2001, Holzwarth and Ma 2011). Due to the importance in TE processes, several different materials have been investigated to develop potential scaffolds, such as ceramics (e.g. hydroxyapatite and tricalcium phosphate) and polymers (Sachlos and Czernuszka 2003, Guo and Ma 2014). For example, polymers have been reported to have a greater potential as scaffolds for TE purposes due to its processing flexibility and biodegradability (Nair and Laurencin 2007). Synthetic polymers such as aliphatic polyester (e.g. polyglycolic acid, polylactic acid [PLLA], and polycaprolactone [PCL]), polyanhydrides, polyphosphazenes (e.g. alanine and phenylalanine alkyl ester), polyurethanes (PUs) and poly(glycerol sebacate), and natural polymers such as collagen are some of the most commonly used polymers as scaffolds for TE (Freed and Vunjak-Novakovic 1998, Agrawal and Ray 2001, Hutmacher 2001, Sachlos and Czernuszka 2003, Nichol et al. 2013, Guo and Ma 2014, Suhaimi et al. 2015b). Melt moulding, solution casting, phase separation, solventcasting particulate-leaching, emulsion freeze drying, fibre meshes/fibre bonding, freeze drying, and gas foaming are some conventional scaffold fabrication techniques cited in the literature (Sachlos and Czernuszka 2003).

Meneghello et al. (2009) fabricated poly(lactic-coglycolic acid)/polyvinyl alcohol (PVA) blended hollow fibre membranes, where the results demonstrated that $5 \%(\mathrm{w} / \mathrm{w})$ addition of PVA helped to better transport the cell culture medium (CCM) and its constituents. Bettahalli et al. (2011a,b) developed polylactic acid (PLLA) hollow fibre membranes to test the delivery capability of these membranes to diffuse nutrients to the cells. Results showed that the transport of nutrients was high at a rate of $1963 \mathrm{l} /\left(\mathrm{m}^{2} \mathrm{~h}\right.$ bar). In the same year, De Napoli et al. (2011) investigated cell growth in layers of medical microporous polypropylene hollow fibre membranes, and the results showed cells formed thick multilayer among the membranes. More recently, Bettahalli et al. (2014) developed a multilayer scaffold by rolling PLLA electrospun sheets with a multibore hollow fibre membrane, and the results showed that the concept illustrated a good potential for developing complex and thicker tissues. Diban et al. (2014) developed a biodegradable poly( $\varepsilon$-caprolactone) scaffold, and results indicated good cell attachment, proliferation, and penetration into the scaffold. Permeance tests also indicated high water permeabilities, which is a positive indication of nutrient delivery into the cells.

Earlier, Ellis and Chaudhuri (2007) developed a HFMB based on poly(lactide-co-glycolide) (PLGA) sheets. Their results showed that varying the air gap and spinning temperature significantly changed the morphology of the hollow fibre membrane scaffold, allowing larger macrovoids and thicker skin formed. This is one step forward in addressing the size limitations in tissue engineered constructs for clinical practice. Chaudhuri et al. (2008) fabricated honeycomb-structured poly(DL-lactide) and poly[(DL-lactide)-co-glycolide] films using water droplet templating method. Osteoblast cells were able to attach and proliferate on these films, suggesting the potential of its application as TE scaffold. In the same year, Ellis and Chaudhuri (2008) studied the combination of three different lactide:glycolide ratios, and results showed that any ratio was able to support bone regeneration in vitro. Freed et al. (1993) and Galban and Locke (1999) considered the diffusion of nutrients such as glucose and oxygen in porous scaffolds, and both indicated that restriction diffusion of nutrients did limit cell growth, although it may not be the only limiting factor. 
Since by definition a porous medium consists of a network of open spaces, in which a network of pores and fibres for membranes and scaffolds exists, the molecular diffusion is interrupted by the tortuous channels, and the combination of both porosity and tortuosity characterizes the morphological structure of the porous media (Figure 5). A relationship that takes into account the mass transport by diffusion, porosity, as well as the tortuosity, is summarized in Eq. (1):

$$
D_{e}=D \frac{\varepsilon}{\tau},
$$

where $D_{e}$ is the effective diffusion coefficient of the solute in membranes or/and scaffolds, $D$ is the self-diffusion coefficient of the solute in the liquid that fills the pores, and $\varepsilon$ and $\tau$ are the porosity and tortuosity of the material, respectively, with the assumption that the average pore diameter, $d$, is much greater than the mean free path of the solute diffusing in the given liquid.

Keeping these aspects in mind, the present review aims to give an overview of the diffusion of glucose in membranes and gels/scaffolds for TE applications as well as the self-diffusion of glucose in liquid. In effect, the review is divided into sections that represent the four terms in Eq. (1). Firstly, the paper will discuss the measurements of diffusion of glucose in membranes/scaffolds using various methods available. Secondly, it will deal with the techniques available to measure porosity and tortuosity of the porous media. Thirdly, the review will cover the effects of microstructure on the diffusion process. Lastly, the different methods available for the estimation of glucose self-diffusion in liquids will be reviewed briefly, given that their understanding is also required to quantify the effective diffusion of glucose in the membranes/ scaffolds.

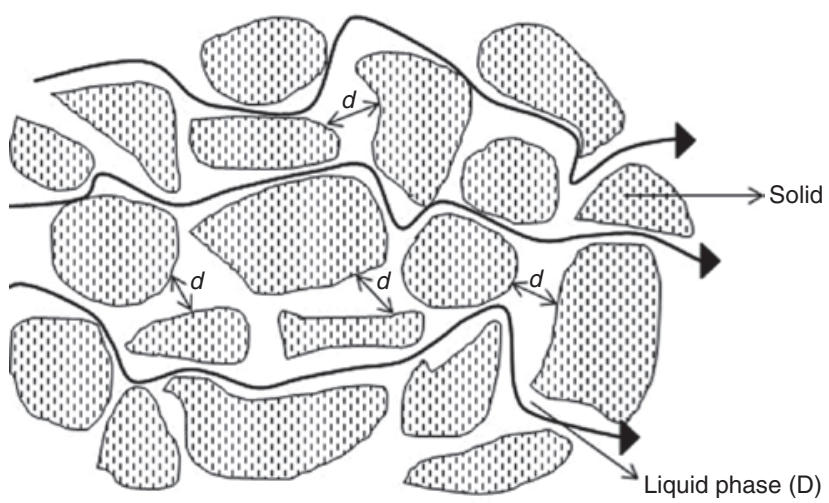

Figure 5: A representation of liquid diffusional pathway in porous media.
The field of TE holds a promising future in such a way that there are some health conditions that cannot be cured just by prescribing some medicines and drugs, such as liver failure and spinal cord failure (Langer 2009). When this happens, apart from organ transplants, which induce immunological responses to name a few, TE is the only hope that remains. It is greatly hoped that the present review will help in understanding the diffusion of nutrient and its effects on the membrane and scaffold microstructure, specifically, and in the field of TE, generally.

\section{Measurements of glucose concentration or diffusivity}

Numerous glucose diffusion studies have been reported for a vast number of applications ranging from TE (Hannoun and Stephanopoulos 1986, Weng et al. 2005, Rong et al. 2006, Papenburg et al. 2007, Wang et al. 2009, Jin et al. 2010, Podichetty et al. 2014), diabetes management (Maier et al. 1994, Wang and Musameh 2003, Boss et al. 2012), modern laser medicine (Chance et al. 1995, Liu et al. 1996, Tuchin et al. 1997, Wang 2000, Vargas et al. 2001, Yao et al. 2002, Bashkatov et al. 2003), pharmaceutics (Andersson et al. 1997), chemical engineering, filtration (Yaroshchuk et al. 2011, Adams et al. 2013), oil and fat industry (Miyagi et al. 2012), and water desalination (Lonsdale et al. 1965, Sherwood et al. 1967). A review of these studies suggests that a number of different techniques could be applied to measure glucose concentration or diffusivity as discussed below.

\subsection{Needle enzyme electrodes}

A number of papers have been reported on the use of needle enzyme electrode to observe glucose diffusion. For example, Rong et al. (2006) presented an interesting work to measure directly the transient glucose concentration at the centre of a specially compressed and rolled collagen gel using needle enzyme electrodes. They first stabilised and calibrated the needle electrodes. Glucose was then oxidised by glucose oxidase enzyme solution to hydrogen peroxide, which was further oxidised to form an amperometric current. The current was read by an AUTOLAB PGSTAT10 potentiostat instrument. They also proposed a computational model to fit the simulated concentration profile to the experimental results. The glucose diffusion coefficient was estimated to be $1.3 \times 10^{-10} \mathrm{~m}^{2} / \mathrm{s}$ (Table 2) in the chosen gel, 


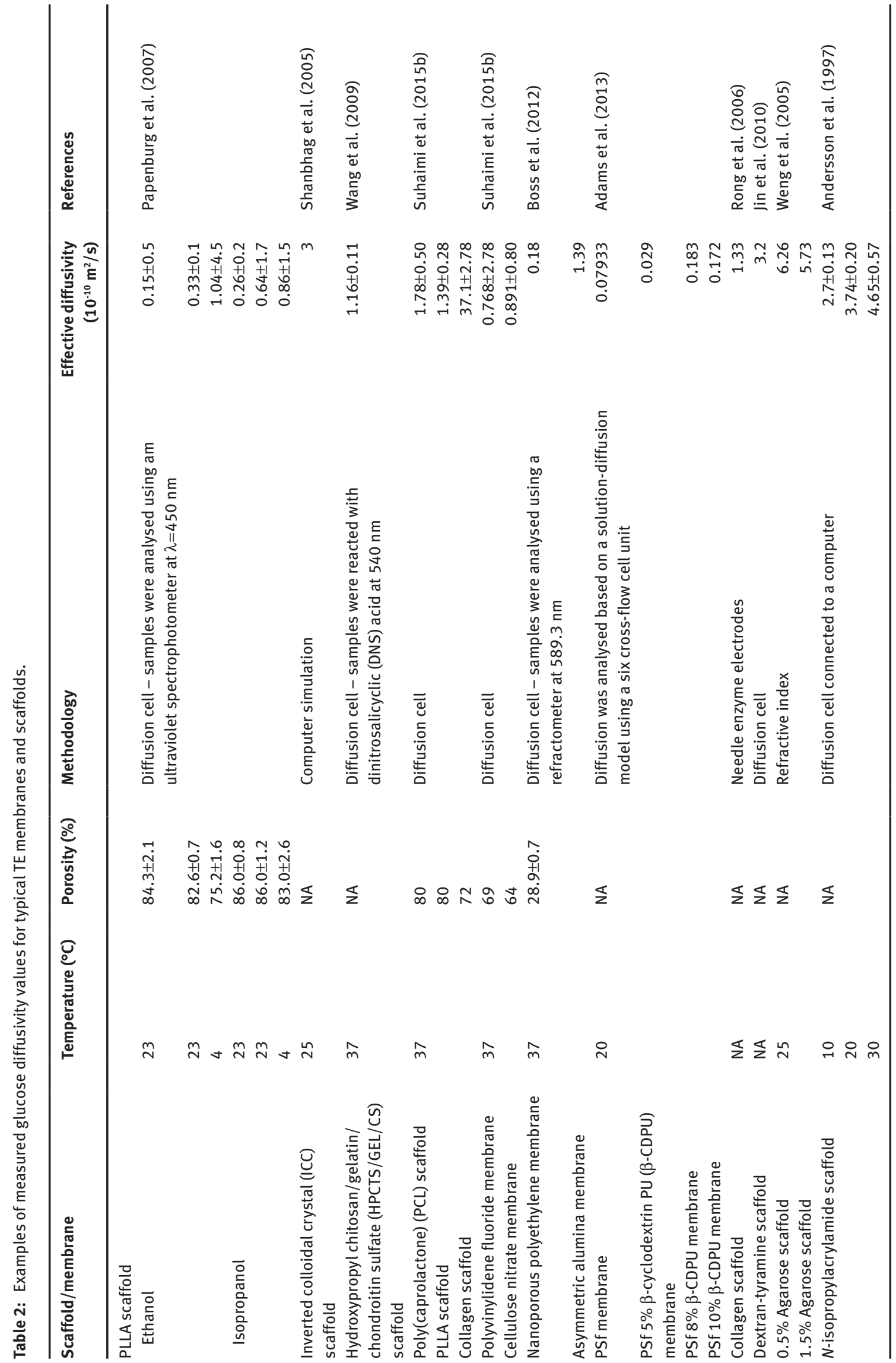


and the authors concluded that potential errors sourced from noise, baseline, and zero time determination were able to be kept as minimum as possible and consequently resulted in higher accuracy. Wang and Musameh (2003) conducted a study on needle enzyme electrodes to observe the potential of this technique for continuous monitoring of glucose, and results demonstrated positive response for future use. Fang et al. (2014) fabricated a glucose electrode coated with PLGA biodegradable membrane to test the long-term stability of the electrode in bovine serum at $37^{\circ} \mathrm{C}$. The condition was to mimic the in vivo environment, and their results showed that $80 \%$ of its sensitivity was retained after 44 days inside the serum. They concluded that glucose sensors exhibited a good potential for realtime measurements of glucose concentrations inside the body. Glucose biosensors have been developed for over 50 years, with the aim of continuous measuring of glucose level. An error of $<20 \%$ for glucose concentrations ranging between 1.65 and $22 \mathrm{mmol} / \mathrm{l}$ should be followed as recommended by the U.S. Food and Drug Administration (Yoo and Lee 2010). Needle enzyme electrode is seen as a good and reliable biosensor for measuring glucose concentration both in vitro and in vivo.

\subsection{Diffusion cell}

Diffusion cell technique has been used regularly used since Hannoun and Stephanopoulos (1986) measured both ethanol and glucose diffusivities in calcium alginate membranes, both seeded and not seeded with cells. More recently, Jin et al. (2010) studied the diffusion of glucose in different molecular weights of dextran-tyramine hydrogels to determine the ability of these hydrogels as injectable scaffolds for TE applications. They used a diffusion cell consisted of two chambers with identical volumes. Both chambers were filled with glucose solution and distilled water, respectively. The diffusion cell was subjected to a $37^{\circ} \mathrm{C}$ water bath. The concentration of glucose in both chambers were analysed using an ultraviolet spectrophotometer at a wavelength of $450 \mathrm{~nm}$. Jin et al. (2010) also employed an enzyme-based system to help measure the glucose concentration. As what can be expected of diffusion work in similar cases, the glucose concentration in the glucose-solution-filled chamber decreased, while that of the distilled-water-filled chamber increased accordingly before reaching a plateau after 3 days. They also concluded that different molecular weights and degree of substitution of TA groups work well with glucose diffusion, where in all cases, over $70 \%$ of glucose diffused was observed.
Papenburg et al. (2007), in an attempt to observe the glucose diffusion in their own fabricated PLLA micropatterned sheets, also employed a diffusion cell. The glucose diffusion coefficient was measured to be $0.8-0.1 \times 10^{-10} \mathrm{~m}^{2} / \mathrm{s}$ (Table 2). Boss et al. (2012) used the diffusion cell to measure the glucose diffusion coefficient across nanoporous alumina membrane, and results showed a value of $1.35( \pm 0.31) \times 10^{-10} \mathrm{~m}^{2} / \mathrm{s}$ (Table 2). More recently, Suhaimi et al. (2015b) adopted the diffusion cell method to determine the glucose diffusion coefficient in typical TE membranes and scaffolds (Figure 6) saturated with water and cell CCM. Their results demonstrated reduced glucose diffusivities in materials saturated with CCM (e.g. from $1.20 \pm 0.38 \times 10^{-10} \mathrm{~m}^{2} / \mathrm{s}$ to $0.728 \pm 3.37 \times 10^{-10} \mathrm{~m}^{2} / \mathrm{s}$ for polyvinylidene fluoride membrane). Diffusion cell method is valid under the assumption of steady-state systems, which make use of Fick's first law to measure the glucose diffusivity.

\subsection{Refractive index method}

A group of researchers (Weng et al. 2005) attempted to further understand the glucose behaviour in agarose gel, which has a significant effect in molecular diffusion research in general and TE in particular. For this particular work, they adopted a refractive index method as a means to measure the glucose diffusion coefficient in the agarose gel. The gel was contained inside a triangular cell, where it was later immersed into the glucose solution. When this happened, the change of light was captured by a chargecoupled device (CCD) camera and post processed with specific software. The source of light came from a He-Ne laser. This method presents some advantages over others due to its capability to measure concentration in situ without interrupting the process as well as the simple post processing work thereafter. As such, the method has been used since in the early 1990s up until recently (Maier et al. 1994, Chance et al. 1995, Liu et al. 1996, Tuchin et al. 1997, Wang 2000, Vargas et al. 2001, Yao et al. 2002, Bashkatov et al. 2003, Zhang et al. 2013a,b, Trichet et al. 2014, Ullah et al. 2014, Pleitez et al. 2015).

In general, when light passes through a prism, some, if not all, will be refracted back in what is known as refractive angle. This refractive angle resembles refractive index of the prism. Weng et al. (2005) indicated in their work the success of monitoring glucose transport in the agarose gel as well as determining the diffusion coefficients using the method. They deduced $5.73 \times 10^{-10} \mathrm{~m}^{2} / \mathrm{s}$ (Table 2 ) as the diffusivity in $1.5 \%$ agarose gel at $25^{\circ} \mathrm{C}$. This figure is comparable to the value of Andersson and Oste (1994), whose work 

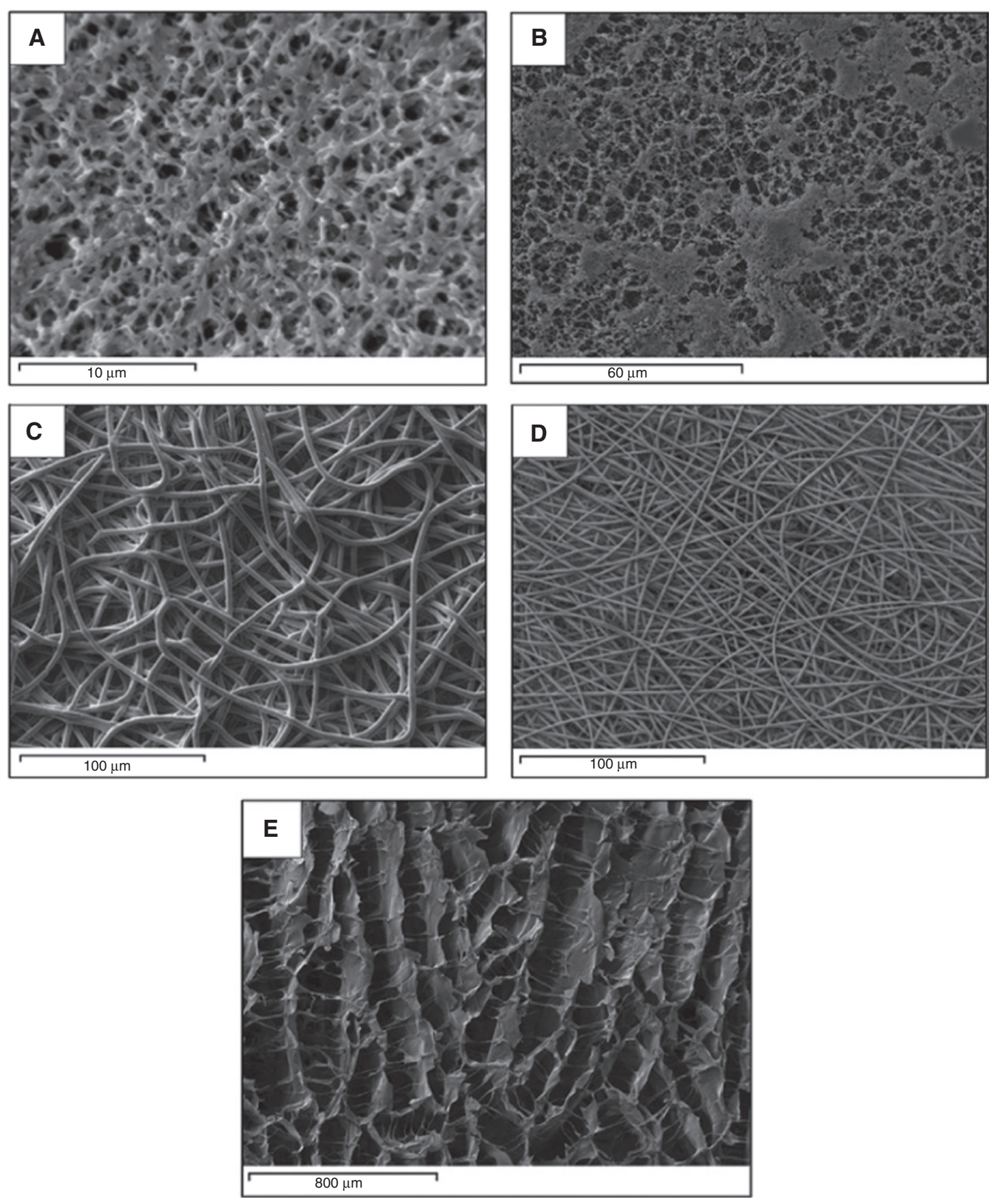

Figure 6: SEM micrographs showing the surface morphology of (A) polyvinylidene fluoride (PVDF) membrane, (B) cellulose nitrate membrane, (C) poly(caprolactone) scaffold, (D) poly(L-lactide) scaffold, and (E) collagen scaffold (Suhaimi et al. 2015b).

monitored the glucose diffusion in 1.2\%-3.6\% agarose gel at $25^{\circ} \mathrm{C}$ using a steady-state diaphragm cell. The obtained diffusion coefficients were around $4.25-6.15 \times 10^{-10} \mathrm{~m}^{2} / \mathrm{s}$, which is close to what Weng et al. (2005) obtained. Another pertinent work by Li et al. (1996) can be taken as a comparison, where they observed the glucose diffusion in $0.197 \%$ agarose gel at $37^{\circ} \mathrm{C}$. The comparison indicated that the obtained glucose diffusivity was at least $50 \%$ more than what Weng et al. (2005) obtained. They also compared the diffusivities of glucose in $0.5 \%$ and $1.5 \%$ agarose gel, and as expected, $0.5 \%$ agarose gel showed a slightly higher diffusion coefficient of $6.26 \times 10^{-10} \mathrm{~m}^{2} / \mathrm{s}$ due to lower polymer content, resulting in higher glucose mobility.

In 2006, Liang et al. (2006) attempted to improve the in situ refractive index method with temperature-controlled capability. They used protein instead of glucose to 
measure the diffusion coefficient in agarose gel. Results proved that this improved method was reliable in measuring the protein diffusion at different temperatures. There seems to be no recent study reported on the use of refractive index method to monitor the glucose diffusion in TE materials. However, this method has been used recently to measure glucose level in tissue sample, and one such study is reported by Ullah et al. (2014), where they used the refractive index method to measure the glucose level in mouse blood. The aim of their study was to further understand the use of laser applications to determine blood glucose levels without incision. Their results showed a positive indication for future applications. This technique is suitable for materials such as transparent gel-like scaffolds since it involves light transmission from and to the solute molecules in the gel to capture the speed.

\subsection{Dispersion model method}

Apart from the polymer content of a gel matrix, the working temperature of the diffusion process also has an impact on the diffusing solute molecules. Andersson et al. (1997) conducted a temperature-dependent study on the effect of glucose diffusion at $10^{\circ} \mathrm{C}, 20^{\circ} \mathrm{C}$, and $30^{\circ} \mathrm{C}$ in a swelling $\mathrm{N}$-isopropylacrylamide gel using a dispersion model method. They noted in their report that due to dispersion and time delay during the actual experiment, the concentration recorded by the detector was different to the in situ concentration in the diffusion cell. For these reasons, they fitted the experimental concentration profiles into a mathematical model that corrected both the dispersion and time delay factors. The calculated diffusion coefficients of glucose at $10^{\circ} \mathrm{C}, 20^{\circ} \mathrm{C}$, and $30^{\circ} \mathrm{C}$ are summarized in Table 3. They concluded that the glucose diffusivity agreed with Wilke-Chang temperature correlation (Wilke and Chang 1955), suggesting that the change in diffusivity was mostly due to the change in temperature, not due to the degree of gel swelling. On the other hand, Podichetty et al. (2014) reported that the use of dispersion model coupled with residence time distribution analysis to observe the distribution of glucose in PCL scaffold

Table 3: Effective diffusivities of glucose in swelling $\mathrm{N}$-isopropylacrylamide gel (Andersson et al. 1997).

\begin{tabular}{lr}
\hline Temperature $\left({ }^{\circ} \mathrm{C}\right)$ & Effective diffusivity $\left(\mathrm{m}^{2} / \mathrm{s}\right)$ \\
\hline 10 & $2.70( \pm 0.13) \times 10^{-10}$ \\
20 & $3.74( \pm 0.20) \times 10^{-10}$ \\
30 & $4.65( \pm 0.57) \times 10^{-10}$ \\
\hline
\end{tabular}

and chitosan-gelatin scaffold. Their results showed that the surface properties of scaffolds had an effect on the glucose distribution and concluded that the combined approach gave useful insights to designing bioreactors for tissue regeneration. Since this method combines both experimental and modelling approaches, the mathematical model is validated by experimental measurements. The method is valid for small molecule in diluted and uncharged gel systems.

\subsection{Six cross-flow cell unit method}

A number of studies of glucose transport through different types of membranes have been carried out, but no or little work has been reported on the glucose diffusion in polymeric/cyclodextrin mixed-matrix membranes. Thus, Adams et al. (2013) presented a noble work on the transport of glucose through polysulfone (PSf)/ $\beta$-cyclodextrin PU mixed-matrix membranes of three different PSf concentrations. The surface morphology of the mixed-matrix membranes showed uniformly sized circular voids of a smooth structure (Figure 7).

Before conducting the investigation, the membranes were subjected to a pressure of 3.10 MPa for a period of $2 \mathrm{~h}$, and, specifically for diffusion experiments, they were conditioned to a pH of 6.89 and a temperature of $20^{\circ} \mathrm{C}$. The diffusion coefficients of glucose were calculated based on Fick's diffusion law assuming the concentration difference was the sole driving force. The corresponding diffusion coefficients are shown in Table 4. The authors concluded that mixed-matrix membranes performed well in diffusing glucose due to its increased hydrophilicity as well as its crystal structure. This method, which applies solution-diffusion system, is typically applicable for nonporous membranes in which the difference between solubility and diffusivity leads to separation of permeates. Table 2 summarises the different methodologies used for measurements of glucose diffusion in various membranes and scaffolds as well as the corresponding effective diffusion coefficients values from these studies.

\section{Porosity and tortuosity of TE membranes and scaffolds}

Besides the interactions between the diffusing solute and the porous network in membranes and scaffolds, the amount of void spaces (porosity) and the tortuous path length (tortuosity), which increases the distance a 

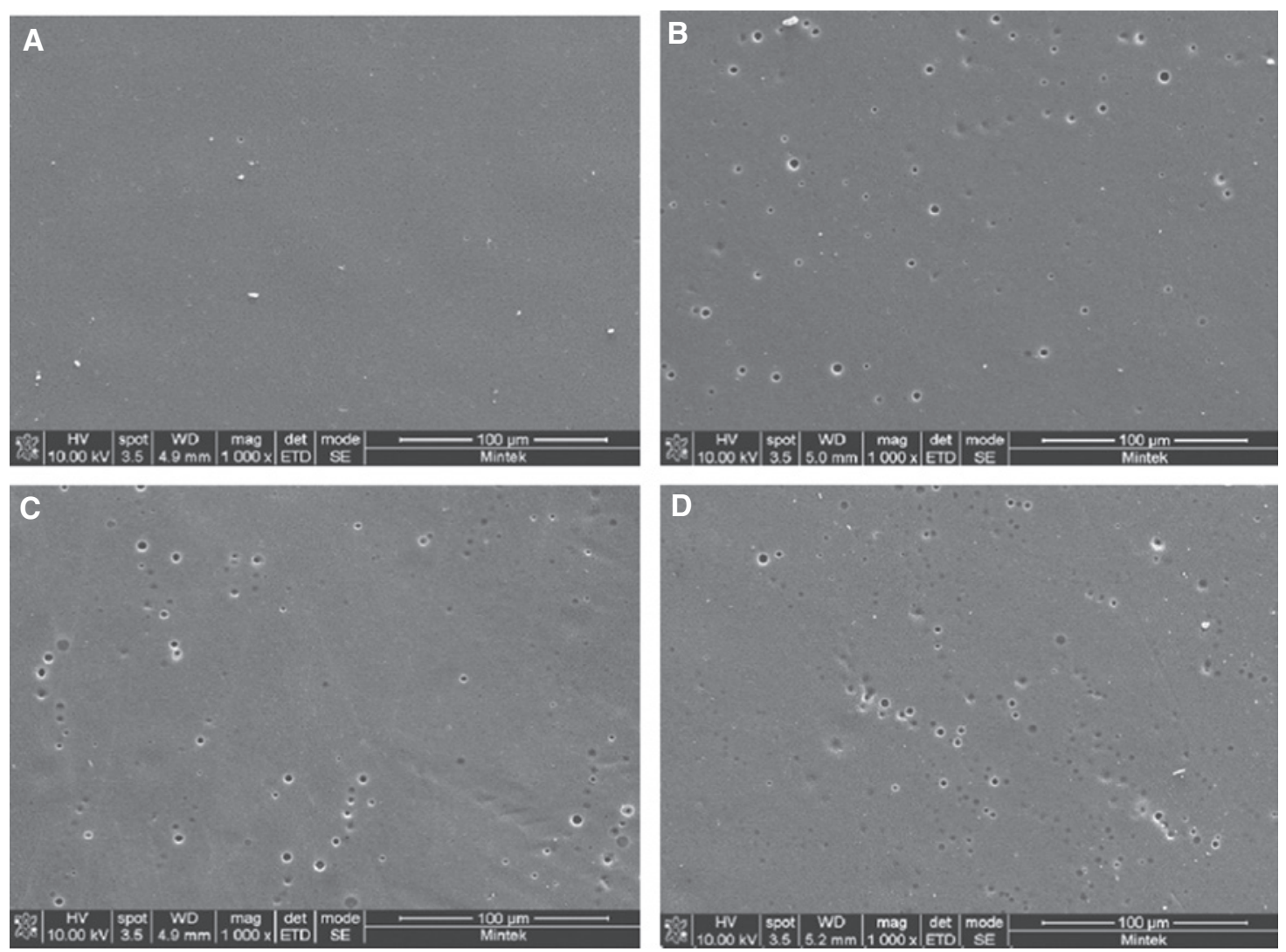

Figure 7: SEM micrographs showing surface morphology of (A) PSf membrane, (B) PSf $5 \%$-cyclodextrin PU (CDPU) membrane, (C) PSf $8 \%$ $\beta$-CDPU membrane, and (D) PSf $10 \% \beta$-CDPU membrane (Adams et al. 2013; reproduced with permission of Elsevier).

Table 4: Glucose diffusivities in mixed-matrix membranes (Adams et al. 2013).

\begin{tabular}{lr}
\hline Membrane type & Effective diffusivity $\left(\mathrm{m}^{2} / \mathrm{s}\right)$ \\
\hline PSf & $0.0793 \times 10^{-10}$ \\
PSf $5 \% \beta$-cyclodextrin PU ( $\beta$-CDPU) & $0.0290 \times 10^{-10}$ \\
PSf $8 \% \beta$-CDPU & $0.1833 \times 10^{-10}$ \\
PSf $10 \% \beta$-CDPU & $0.1717 \times 10^{-10}$ \\
\hline
\end{tabular}

molecule has to traverse through the pore network, also have significant effects on the mass transport.

Porosity can be determined using either indirect or direct techniques. Examples of indirect techniques include liquid permeability (Palacio et al. 1999), permporometry (Mey-Marom and Katz 1986), air-liquid porometry (Hernandez et al. 1996), liquid-liquid porometry (Bechhold et al. 1931), scanning electron microscopy (SEM) (Riedel and Spohr 1980), transmission electron microscopy (TEM) (Nakao 1994), atomic force microscopy (AFM) (Binnig et al. 1986), field emission SEM (FESEM) (Dietz et al. 1992), thermoporometry (Brun et al. 1977), and gas adsorption-desorption
(Dollimore and Heal 1964, Gregg and Sing 1982). On the other hand, pycnometric methods, mercury intrusion, and apparent density estimation are some examples of direct techniques for measuring porosity (Palacio et al. 1999).

Comparisons between using direct and indirect techniques will be highlighted here. While the pycnometric method appears to be easy and simple, it can lead to hydration problem, which will have a significant effect on the porosity determination. Instead of wetting the porous material with water, mercury as the wetting agent has been proven to be more precise (Liabastre and Orr 1978). However, only certain pore sizes are able to work well with Hg-porosimetry due to a considerable amount of pressures needed to infuse mercury into very fine pores. Apparent density estimation is also another simple and easy method to comprehend, yet it tends to overestimate porosities, which may be due to hydration and the presence of contaminants as well as non-pure materials, whose densities are unaccountable for in the calculation of porosity. A common setback of using these direct techniques is the ability to detect non-active pores or dead-end pores in the porous materials. 
Microscopic methods such as SEM, TEM, AFM, and FESEM present surface and cross-section micrographs of the porous material, and these images can be uploaded onto a computer and analysed using special software that enable surface porosity to be determined easily. However, the bulk porosity requires the cross section images to be captured at certain angles, which will eventually distort the overall structure. The air-liquid and liquid-liquid porometry techniques require two steps: the first one is to produce a flow graph against pressure or the resulting pore diameter, which can be deduced using Washburn equation (Washburn 1921). This step requires a suitable air and liquid to be pressurised in order to diffuse into the pores, while the second step involves integrating the cross-section area of the pore diameter, which results to porosity determination.

Palacio et al. (1999) reported the outcome using a gas penetration method in view of experimental and nominal porosities, and they acknowledged the difference between these two. This may be due to a lack of information from the manufactures on the techniques used to obtain the nominal values; therefore, comparisons of using the same method to confirm the porosity values are not possible. The nominal values are merely a representative for the same batches of the same membrane material and therefore cannot be truly justified. This method is preferred if all voids are to be investigated and also benefits from minimising structure distortion as only minimal pressures are required.

Tortuosity is defined by the increased distance that the diffusing solution has to travel due to pore bending and curves. Porosity, diffusion coefficient, and tortuosity are correlated (Van Cappellen and Gaillard 1996), and the latter can be determined experimentally, theoretically, and empirically. Shen and Chen (2007) reviewed two experimental methods: one is the work of Sweerts et al. (1991) aimed at determining the ratio of diffusivity in free media to the diffusivity in a porous material of known porosity, while the other one is the work of McDuff and Ellis (1979) aimed at determining diffusivities of marine sediments. They linked tortuosity to a formation factor obtained via electrical resistivity measurements. The former is time consuming while the latter needs electrical resistivity probes.

Theoretical methods of correlating porosity and tortuosity are generally based on the assumption of an idealised porous medium with the absence of adjustable parameters. Examples of such models can be seen in the works of Bhatia (1985), Dykhuizen and Casey (1989), and Petersen (1958). In contrast to the theoretical method, the empirical method encompasses adjustable parameters
Table 5: Porosity-tortuosity relations for idealised porous materials.

\begin{tabular}{ll}
\hline Relation & References \\
\hline$\tau=1-0.41 \ln \varepsilon$ & Comiti and Renaud (1989) \\
$\tau=1-0.49 \ln \varepsilon$ & Mauret and Renaud (1997); Barrande et al. (2007) \\
$\tau=1 / \varepsilon^{0.33}$ & Bear (1972); Dullien (1975) \\
$\tau=1+0.8(1-\varepsilon)$ & Koponen et al. (1996) \\
$\tau^{2}=1-\ln \left(\varepsilon^{2}\right)$ & Boudreau (1996) \\
$\tau=\frac{\varepsilon}{1-(1-\varepsilon)^{1 / 3}}$ & Beeckman (1990) \\
\hline
\end{tabular}

that differ in values in traditional literatures. The first reported work involving the empirical method is the work of Archie (1942). Some examples of the relationship between porosity and tortuosity for idealised porous material can be found in Table 5 .

Suhaimi et al. (2015b) determined both porosity and tortuosity values for TE membranes and scaffolds experimentally. All materials were saturated with both water and $\mathrm{CCM}$ at temperatures of $27^{\circ} \mathrm{C}$ and $37^{\circ} \mathrm{C}$. Porosity was evaluated using a pycnometric method, while tortuosity was derived from the determination of the ratio of diffusivity in free media to the effective diffusivity in the porous network (i.e. TE membranes and scaffolds). The corresponding porosity and tortuosity values are shown in Table 6. They concluded that tortuosities varied with temperature as what has been reported previously (Gao et al. 2014, Sadighi et al. 2013, Sharma and Chellam 2005).

\section{Microstructure and diffusion}

The relationship between nutrient diffusion (i.e. glucose in this paper) and membrane/scaffold morphology or tissue morphology is crucial for better understanding the transport behaviour of the nutrients. In addition, it will help to further improve the computational modelling work with regard to nutrient supply to the cells. An example of the relationship between solute diffusivity and tissue morphology is shown in the work of Shi et al. (2013). Temporomandibular joint (TMJ) disc, a fibrocartilaginous tissue, was taken as their tissue sample and five regions, namely, anterior, medial, intermediate, lateral, and posterior in three orthogonal orientations: medial-lateral, anterior-posterior, and superior-inferior were subjected to fluorescein diffusion. The diffusion process was analysed by a fluorescence recovery after photobleaching (FRAP) technique. All the tissue samples were examined using SEM for the purpose of observing the tissue morphology, that is, the collagen fibre structure (Figure 8). 
Table 6: Porosity and tortuosity values in TE membranes and scaffolds (Suhaimi et al. 2015b).

\begin{tabular}{|c|c|c|c|c|c|}
\hline \multirow[t]{2}{*}{ Material } & \multirow{2}{*}{$\begin{array}{r}\text { Porosity } \\
(\%)\end{array}$} & \multicolumn{4}{|c|}{ Tortuosity (dimensionless) } \\
\hline & & Water at $27^{\circ} \mathrm{C}$ & Water at $37^{\circ} \mathrm{C}$ & $\mathrm{CCM}$ at $27^{\circ} \mathrm{C}$ & $\mathrm{CCM}$ at $37^{\circ} \mathrm{C}$ \\
\hline Polyvinylidene fluoride membrane & 69 & 4.0 & 3.5 & 5.4 & 5.6 \\
\hline Cellulose nitrate membrane $(\mathrm{CN})$ & 64 & 2.4 & 3.1 & 4.8 & 4.4 \\
\hline PLLA scaffold & 80 & 2.7 & 3.0 & 3.3 & 3.5 \\
\hline Poly(caprolactone) scaffold (PCL) & 80 & 1.6 & 1.9 & 2.8 & 2.8 \\
\hline
\end{tabular}

Shi et al. (2013) stated that the collagen fibre orientation may influence the fluorescein (a molecule that is similar to glucose in terms of molecular weight) diffusion based on the inhomogeneous and anisotropic diffusion style of the fluorescein in the TMJ tissue. Furthermore, both the anisotropic diffusion and collagen fibre orientation showed same degrees of similarity and trends in all five regions investigated. They demonstrated that the fluorescein diffusion was dependent on the composition of the region.

Another similar example can be seen in the work of Travascio et al. (2009), where they observed the diffusion of fluorescein in human annulus fibrosus (AF) via the FRAP technique. The diffusion process spanned across three regions namely inner $\mathrm{AF}$ (IAF), middle AF (MAF) and outer $\mathrm{AF}(\mathrm{OAF})$ in two directions, axial and radial, respectively. They concluded that their findings in a similar fashion to Shi et al. (2013), stating that a relationship between solute diffusivity in the human AF and the morphological structure and content of the tissue existed. This hypothesis was drawn based on the similar trend of both diffusivity values and water content, whereby higher water content as well as higher diffusivity value were determined in the IAF region compared to the OAF region. The morphological structure of the tissue samples was analysed using SEM (Figure 9).

An additional example that verified the relationship between transport property and morphological structure of the porous material is illustrated in the work of Li et al. (2007). They fabricated sulfonated poly(ether ether ketone ketone)s (SPEEKK) membranes (Table 7) and observed the morphologies using TEM and AFM (Figure 10).

\section{Glucose diffusivities in liquids}

Attempts to deduce liquid diffusivities have been ongoing, dating back over many decades ago, and by far, the most frequently used method is a diaphragm cell method (DCM). The DCM has been used as early as some
60 years ago up until now (Mills 1957, Wendt and Shamim 1970, Choy et al. 1973, Tham et al. 1973, Turhan et al. 1995, Breer et al. 2014, Buzier et al. 2014) due to its precise and accurate measurements. Other methods have surfaced recently, such as Taylor dispersion method using a long capillary tube (Ribeiro et al. 2006 and 2014), static and dynamic light scattering (Soraruf et al. 2014), open-end capillary method (OECM) (Ouerfelli et al. 2014), and total internal reflection fluorescence microscopy (TIRF) (Uehara et al. 2014).

Generally, the DCM consists of two half-glass compartments with stirrers attached to both and a diaphragm in the middle to separate the content of the compartments. The diaphragm differs in every experiment, ranging from track-etched membrane, porous disk, dialysis paper, and to glass sinter membrane depending on the molecular size of the diffusing solutes. Both compartments are filled with the diffusing solution and distilled water, respectively. Samples are withdrawn from both compartments at allocated time intervals for measurement of concentration. The whole experimental set-up is conditioned to a working temperature.

The corresponding diffusion coefficient by the DCM method is given by

$$
D=\frac{1}{\beta t} \ln \left(\frac{C_{\text {lower }}^{0}-C_{\text {upper }}^{0}}{C_{\text {lower }}^{0}-C_{\text {upper }}}\right),
$$

where $\beta$ is the cell calibration constant, which must be determined before the start of the diffusion experiment. The diaphragm cell is calibrated by performing a diffusion experiment of solute of known diffusivity at the same experimental conditions.

The Taylor dispersion method is typically used to investigate mutual diffusion coefficients of aqueous solutions. It involves a long capillary tube where it houses a number of ports for inlet point. The diffusing solution is injected into the ports and a metering pump is used to keep the flow consistent. The concentration of the dispersed injected sample is analysed by a differential refractometer 
A

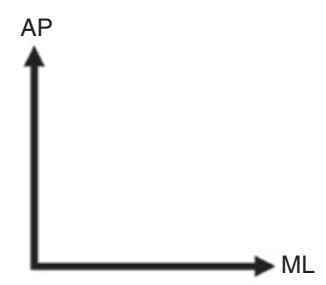

Horizontal XY plane

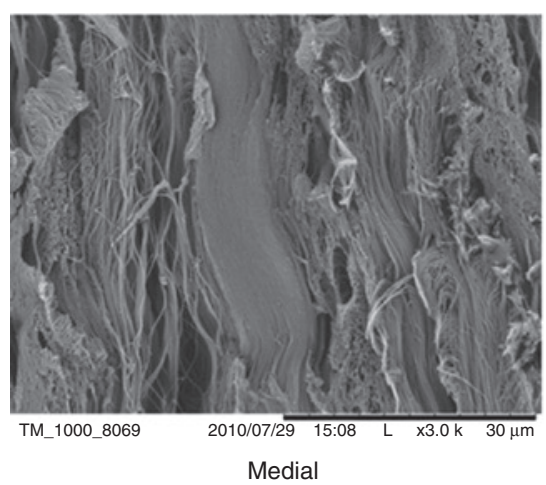

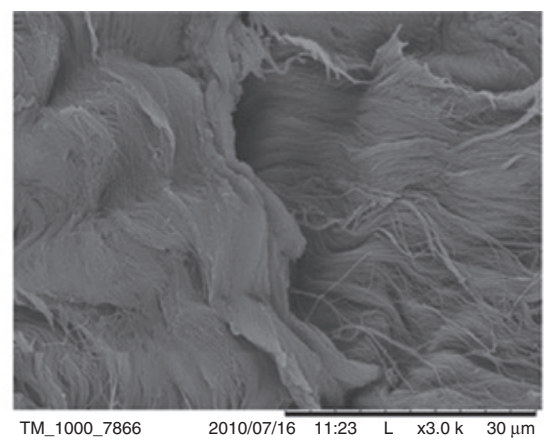

Anterior

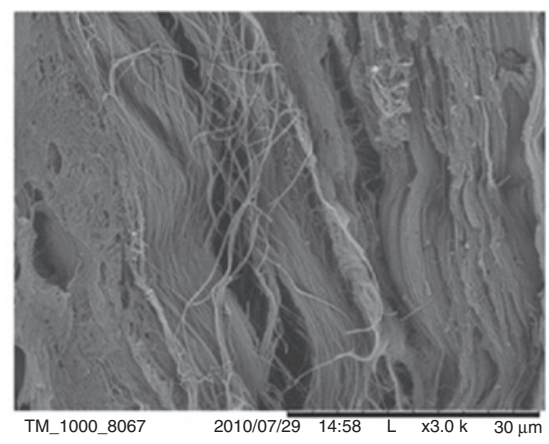

Intermediate

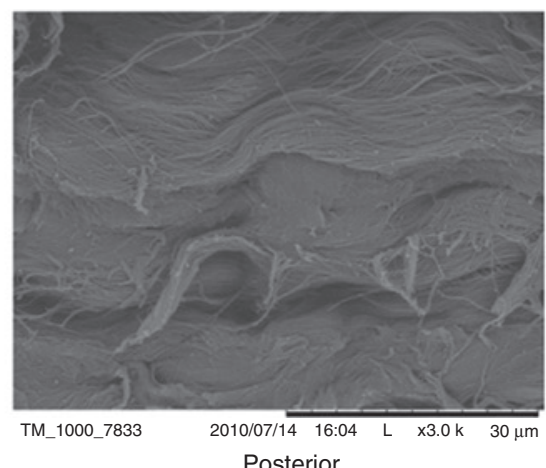

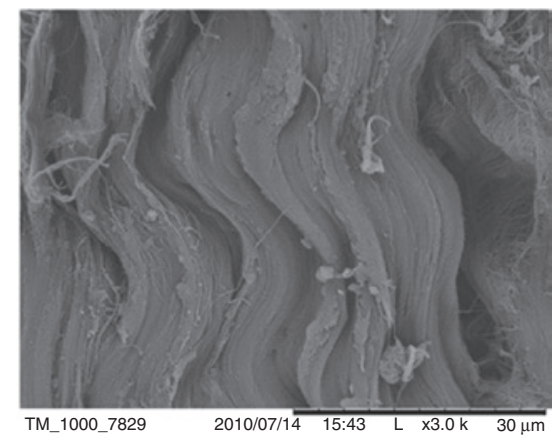

Lateral

Figure 8: SEM micrographs showing the anterior-posterior-medial-lateral orientation of the collagen fibre in all five regions of the TMJ disc (Shi et al. 2013; reproduced with permission of Elsevier).

and the equivalent diffusion coefficient is calculated via the dispersion equation which followed the Gaussian concentration profile:

$$
D=\frac{R^{2}}{48 \bar{t}}\left[\frac{\left(1+4 K^{2}\right)^{1 / 2}+3}{\left(1+4 K^{2}\right)^{1 / 2}+2 K^{2}-1}\right]\left\{1+\left(1-\delta_{a}\right)^{1 / 2}\right\},
$$

where $R$ and $\bar{t}$ are capillary tube radius and mean residence time, respectively, while $K$ and $\delta_{a}$ are defined as follows:

$$
\begin{aligned}
& K=\sigma / \bar{t}, \bar{t}=L / \bar{u}, \delta_{a}=(768)^{2} \Theta \zeta_{0} \\
& \text { and } \zeta_{0}=\frac{2 \sigma^{2}-\bar{t}^{2}+\left(\bar{t}^{4}+4 \bar{t}^{2} \sigma^{2}\right)^{1 / 2}}{8 \bar{t}^{2}-4 \sigma^{2}}
\end{aligned}
$$

where $\sigma, L, \bar{u}$, and $\Theta$ are variance, capillary tube length, mean flow velocity, and a constant of $2.17014 \times 10^{-5}$, respectively.

Ouerfelli et al. (2014), in their report, presented the OECM for the purpose of investigating the diffusion of trivalent lanthanide and actinide ions in aqueous electrolyte solutions. They attached radioactive tracer to these solutions and deduced the diffusivity by the following equation:

$$
D=0.4053 \frac{l^{2}}{t} \ln \left(\frac{0.8106}{\Gamma}\right),
$$

where $l, t$, and $\Gamma$ are capillary length, diffusion time, and ratio of final average activity to total activity in the 


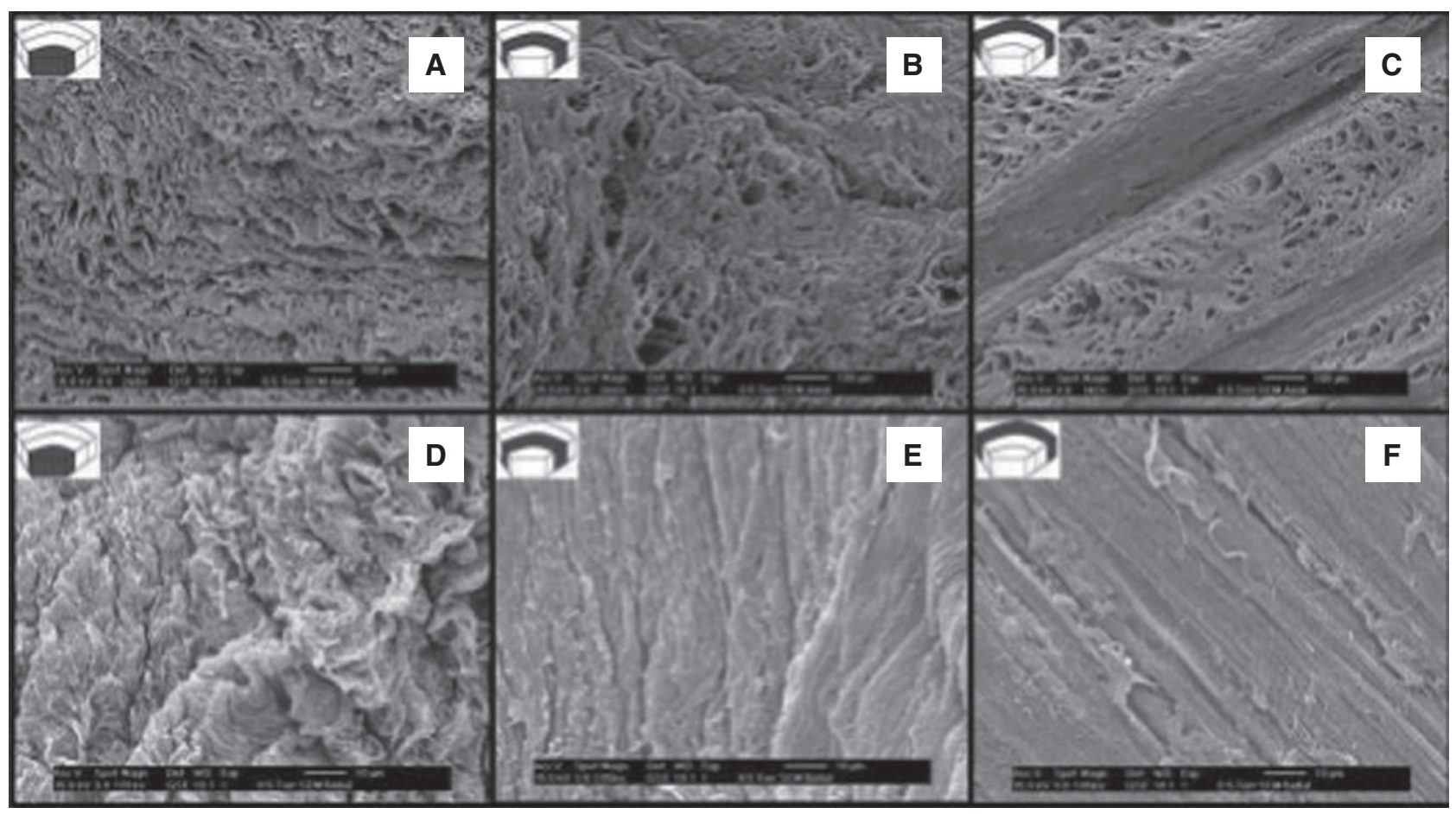

Figure 9: SEM micrographs showing the axial sections of (A) IAF, (B) MAF, (C) OAF and the radial sections of (D) IAF, (E) MAF, and (F) OAF (Travascio et al. 2009; reproduced with permission of John Wiley and Sons).

Table 7: Fabrication details of SPEEKK membranes (Li et al. 2007).

\begin{tabular}{lr}
\hline Membrane & Sulfonated degree $\left(\mathbf{D}_{\mathbf{s}}\right)$ \\
\hline SPEEKK-1 & 0.78 \\
SPEEKK-2 & 0.97 \\
SPEEKK-3 & 1.23 \\
\hline
\end{tabular}

capillary tube at initial time $(\Gamma=A(t) / A(0))$, respectively. Eq. (5) is valid only for concentrations up to $0.114 \mathrm{~mol} / \mathrm{l}$. Uehara et al. (2014) reported the diffusion of singlestranded DNA molecules (ssDNAs) in aqueous solutions by the TIRF technique (Figure 11).

The corresponding diffusion coefficients were evaluated based on their mean square displacements:

$$
D=\lim _{t \rightarrow \infty} \frac{1}{2 n_{\mathrm{dim}} t}\left\langle r(t)-\left.r(0)\right|^{2}\right\rangle,
$$

where $r(t), n_{\text {dim }}$, and 〈〉 are the ssDNA molecules' vector position at time $t$, dimension of $r(t)$, and ensemble average, respectively.

More recently, Suhaimi et al. (2015a) measured glucose diffusivity in both CCM and water (as reference fluid) using the DCM principle, and they concluded that the glucose diffusion coefficients in CCM were significantly reduced than the ones in water. This was attributed to the higher dynamic viscosity of CCM compared to water as well as the multi-component interactions present in CCM, although the latter is believed not to be as significant as the former. While many authors assumed the diffusivity in cell culture media to be equal to that in water ( $\mathrm{Li}$ 1982, Abdullah and Das 2007, Clark et al. 2011, Van Winkle et al. 2012), Suhaimi et al. (2015a) highlighted the significant differences between the diffusivities in both media. Table 8 summarises some examples of diffusing solutes and the corresponding diffusivity values that have been reviewed in this section.

\section{Concluding remarks}

Various different techniques have been used and applied to determine the effective diffusion coefficient of small solutes (e.g. glucose) in the porous material such as needle enzyme electrodes, refractive index method, dispersion model method, six cross-flow cell unit method, and diffusion cell. The suitability of each technique depends on the materials' properties to be investigated as well as the validity of each method. For example, the refractive index method is suitable only for transparent materials as light needs to transmit across the transparent gel to capture 

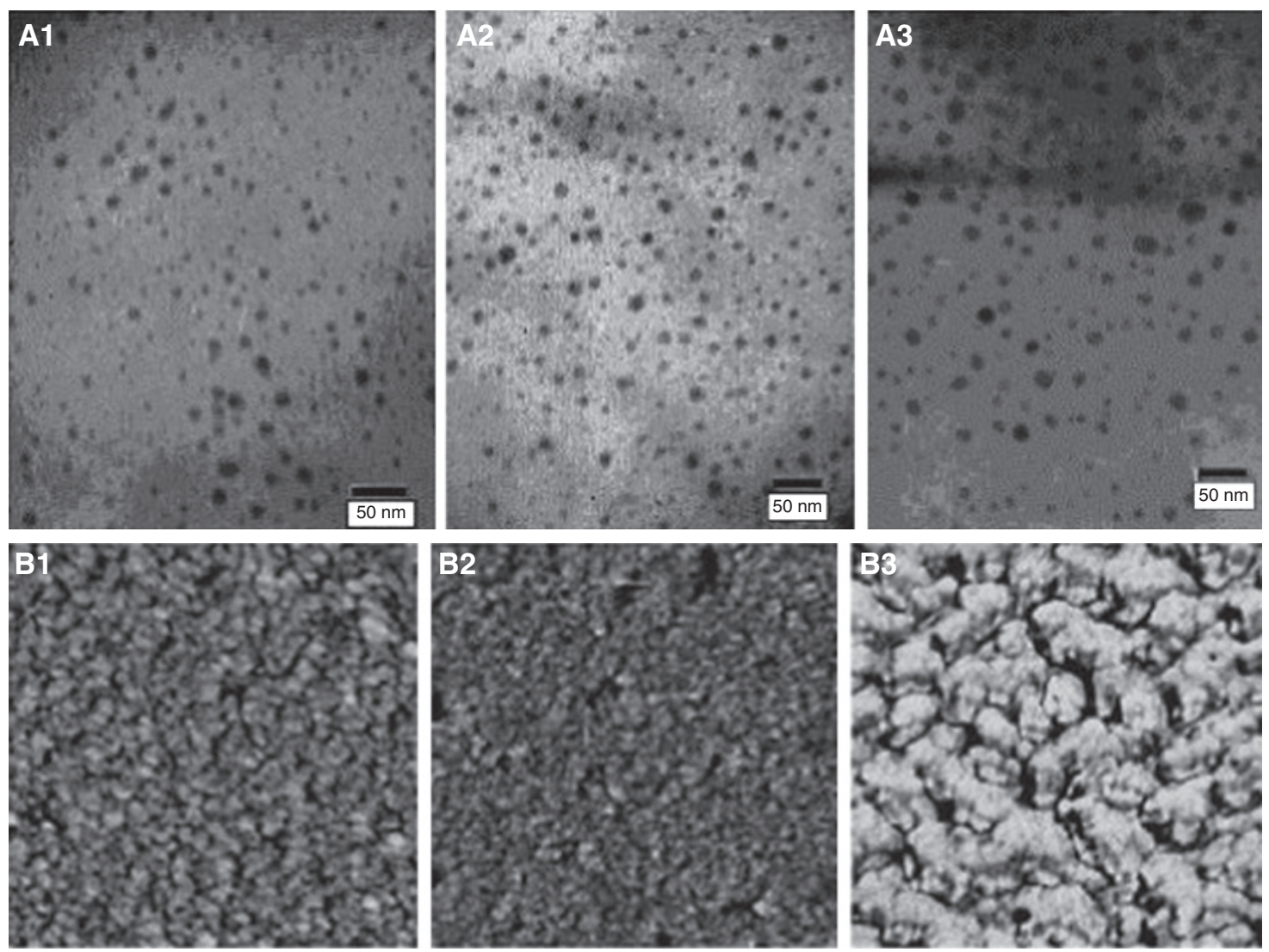

Figure 10: TEM micrographs of (A1) SPEEKK-1, (A2) SPEEKK-2, and (A3) SPEEKK-3 and AFM micrographs of (B1) SPEEKK-1, (B2) SPEEKK-2, and (B3) SPEEKK-3 (Li et al. 2007; reproduced with permission of Elsevier).

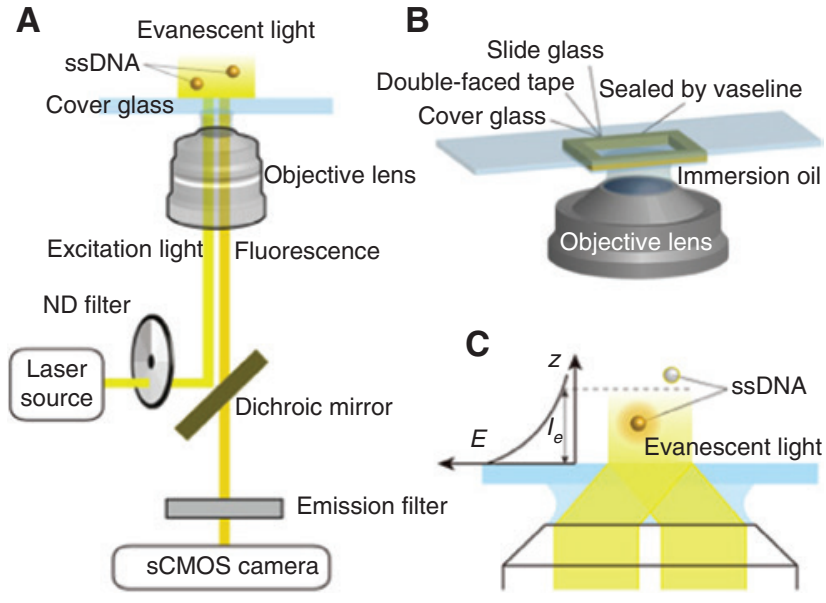

Figure 11: The TIRF technique consisted of (A) optical system, (B) sealing sample solution, and (C) penetration of light (Uehara et al. 2014; reproduced with permission of the Institution of Engineering \& Technology).

its speed of which refractive indexes are translated into concentration measurements. Needle enzyme electrodes, refractive index method, and dispersion model method are shown to require indirect and complicated methods for the concentration measurements of the diffusant across the materials. On the other hand, six cross-flow cell unit and diffusion cell methods are simple and easy to use. We recommend diffusion cell as a way to investigate glucose diffusion in TE materials as it has been widely used and accepted. Moreover, this method works under the assumption of steady-state systems, which is usually the case for glucose diffusion across TE materials, as compared to six cross-flow cell unit, which involves the use of non-porous membranes. For some methods, there is only one or two studies reviewed for the particular method. As the aim of this review paper is to analyse and study methods that have been developed and used over the years in diffusivity measurements, it is still worth mentioning that even though there seems to be fewer studies reported using the methods, they can also be a potential technique for diffusivity determination.

There have been a number of equations developed and produced by various authors based on the methods studied. As such, the equations are used in different applications. For example, DCM will use Eq. (2), while the Taylor dispersion method will employ Eqs. (3) and (4). As the aim of the review paper is not to discuss which 
Table 8: Typical diffusing solutes and their respective diffusivities.

\begin{tabular}{|c|c|c|c|c|}
\hline Diffusing solute & $\begin{array}{l}\text { Temperature } \\
\left({ }^{\circ} \mathrm{C}\right)\end{array}$ & Methodology & $\begin{array}{r}\text { Diffusivity } \\
\left(10^{-10} \mathrm{~m}^{2} / \mathrm{s}\right)\end{array}$ & References \\
\hline Chloride ion & 25 & DCM & 20.33 & Mills (1957) \\
\hline $\begin{array}{l}\text { Water-magnesium chloride- } \\
\text { sodium chloride }\end{array}$ & 25 & DCM & 0.3 & Wendt and Shamim (1970) \\
\hline Sodium ion & 25 & DCM & 7.4 & Choy et al. (1973) \\
\hline Sodium chloride & 25 & DCM & 14.6 & Turhan et al. (1995) \\
\hline Potassium chloride & & & 18.7 & \\
\hline Glucose & & & 6.6 & \\
\hline L-tryptophan & 20 & & 6.52 & \\
\hline Lysozyme & & & 1.09 & \\
\hline Bovine serum albumin (BSA) & & & 6.44 & \\
\hline Aqueous lactose & 25 & $\begin{array}{l}\text { Taylor dispersion method } \\
\text { using a long capillary tube }\end{array}$ & $5.68 \pm 0.035$ & Ribeiro et al. (2006) \\
\hline Aqueous sucrose & & & $5.25 \pm 0.009$ & \\
\hline Aqueous glucose & & & $6.78 \pm 0.020$ & \\
\hline Aqueous fructose & & & $6.89 \pm 0.030$ & \\
\hline Aspartic acid & 25 & $\begin{array}{l}\text { Taylor dispersion method } \\
\text { using a long capillary tube }\end{array}$ & $8.20 \pm 0.010$ & Ribeiro et al. (2014) \\
\hline Monosodium salt & & & $9.35 \pm 0.007$ & \\
\hline $\begin{array}{l}\text { Single stranded DNA } \\
\text { (ssDNA) molecule }\end{array}$ & NA & TIRF & 2.73 & Uehara et al. (2014) \\
\hline Aqueous glucose in water & 37 & NA & 9 & Buchwald (2011) \\
\hline $\begin{array}{l}\text { Aqueous glucose in cell } \\
\text { culture media (CCM) }\end{array}$ & 37 & Stokes-Einstein equation & 5.926 & Provin et al. (2008) \\
\hline \multirow[t]{2}{*}{ Glucose in water } & 27 & DCM & $6.98 \pm 0.60$ & Suhaimi et al. (2015a) \\
\hline & 37 & & $9.58 \pm 0.13$ & \\
\hline \multirow[t]{2}{*}{ Glucose in $\mathrm{CCM}$} & 27 & & $5.67 \pm 0.74$ & \\
\hline & 37 & & $6.16 \pm 1.25$ & \\
\hline
\end{tabular}

equation is the most appropriate one, as the equation used for estimating the liquid diffusivity depends on the method used, we will therefore not state it in this review paper. However, due to its simple, precise, and accurate measurements, DCM has been widely used, and hence, Eq. (2). In addition, with reference to Table 8, DCM seems to be the most frequently used method in determining the liquid diffusivity in free medium. The range of concentration used for DCM is also larger than other methods (Table 8); therefore, we can conclude that DCM is more applicable in wider applications.

Apart from pore size, porosity and tortuosity also affect the diffusion of a molecule through the porous material. Both direct and indirect approaches have been discussed with regard to their respective advantages and disadvantages, and we conclude that there is no general procedure to determine both porosity and tortuosity of the porous media. For example, while pycnometric method seems to be straightforward, it can result in hydration of the samples. Mercury has been proposed as a better wetting agent instead of water for pycnometric technique; however, it is only valid for certain pore sizes. Hence, we conclude that the most appropriate method depends on the materials to be characterized. Sufficient studies have proven that there exists a relationship between the property of transport of solute and morphological structure, and these findings are crucial in better and improved understanding of the nutritional supply to extracellular matrix and cells for TE applications. Despite a number of literature works, the general relationship between membrane morphology and solute diffusion is not fully understood yet as the building blocks of the material varies within the same material, and from one material to another. The temperature and fluid that saturates it may also affect the microstructure, and this, in turn, affects the diffusion.

Acknowledgments: The authors are grateful to the Brunei Government for a PhD scholarship to Hazwani Suhaimi, which made this work possible. The help of Shuai Wang and Chengcheng Cao is gratefully acknowledged.

Conflict of interest: The authors declare that there is no conflict of interest for this paper. 


\section{References}

Abdullah NS, Das DB. Modelling nutrient transport in hollow fibre membrane bioreactor for growing bone tissue with consideration of multi-component interactions. Chem Eng Sci 2007; 62: 5821-5839.

Abdullah NS, Das DB, Ye H, Cui ZF. 3-D bone tissue growth in hollow fibre membrane bioreactor: implications of various process parameters on tissue nutrition. Intl J Artif Org 2006; 9: 841-851.

Abdullah NS, Jones DR, Das DB. Nutrient transport in bioreactors for bone tissue growth: why do hollow fibre membrane bioreactors work? Chem Eng Sci 2009; 64: 109-125.

Abousleiman RI, Reyes Y, McFetridge P, Sikavitsas V. Tendon tissue engineering using cell-seeded umbilical veins cultured in a mechanical stimulator. Tissue Eng Part A 2009; 15: 787-795.

Adams FV, Dlamini DS, Nxumalo EN, Krause RWM, Hoek EMV, Mamba BB. Solute transport and structural properties of polysulfone/ $\beta$-cyclodextrin polyurethane mixed-matrix membranes. J Membr Sci 2013; 429: 58-65.

Agrawal CM, Ray RB. Biodegradable polymeric scaffolds for musculoskeletal tissue engineering. J Biomed Mater Res 2001; 55: 141-150.

Amini AR, Laurencin CT, Nukavarapu SP. Bone tissue engineering: recent advances and challenges. Crit Rev Biomed Eng 2012; 40: 363-408.

Andersson AP, Oste RE. Diffusivity data of an artificial food system. J Food Eng 1994; 23: 631-639.

Andersson M, Axelsson A, Zacchi G. Diffusion of glucose and insulin in a swelling $N$-isopropylacrylamide gel. Int J Pharm 1997; 157 : 199-208.

Archie GE. The electrical resistivity log as an aid in determining some reservoir characteristics. Pet Technol 1942; 1: 55-62.

Baptista RP, Fluri DA, Zandstra PW. High density continuous production of murine pluripotent cells in an acoustic perfused bioreactor at different oxygen concentrations. Biotechnol Bioeng 2013; 110: 648-655.

Barrande M, Bouchet R, Denoyel R. Tortuosity of porous particles. Anal Chem 2007; 79: 9115-9121.

Bashkatov AN, Genina EA, Sinichkin YP, Kochubey VI, Lakodina NA, Tuchin VV. Glucose and mannitol diffusion in human dura mater. Biophys J 2003; 85: 3310-3318.

Bear J. Dynamics of fluids in porous media. New York: American Elsevier, 1972.

Bechhold H, Schlesinger M, Silbereisen K. Porenweite von ultrafiltern. Kolloid-Zeitschrift. 1931; 55: 172-198.

Beeckman JW. Mathematical description of heterogeneous materials. Chem Eng Sci 1990; 45: 2603-2610.

Bettahalli NMS, Vicente J, Moroni L, Higuera GA, van Blitterswijk CA, Wessling M, Stamatialis D. Integration of hollow fiber membranes improves nutrient supply in three-dimensional tissue constructs. Acta Biomater 2011a; 7: 3312-3324.

Bettahalli NMS, Steg H, Wessling M, Stamatialis D. Development of poly(L-lactic acid) hollow fiber membranes for artificial vasculature in tissue engineering scaffolds. J Membr Sci 2011b; 371: 117-126.

Bettahalli NMS, Groen N, Steg H, Unadkat H, de Boer J, van Blitterswijk CA, Wessling M, Stamatialis D. Development of multilayer constructs for tissue engineering. J Tissue Eng Regener Med 2014; 8: 106-119.
Bhatia SK. Directional autocorrelation and the diffusional tortuosity of capillary porous media. J Catal 1985; 93: 192-196.

Binnig G, Quate CF, Gerber CH. Atomic force microscope. Phys Rev Lett 1986; 56: 930-933.

Boss C, Meurville E, Sallese JM, Ryser P. Size-selective diffusion in nanoporous alumina membranes for a glucose affinity sensor. J Membr Sci 2012; 401-402: 217-221.

Boudreau BP. The diffusive tortuosity of fine-grained unlithified sediments. Geochim Cosmochim Ac 1996; 60: 3139-3142.

Breer J, de Groot K, Schonert H. Diffusion in the diaphragm cell: continuous monitoring of the concentrations and determination of the differential diffusion coefficient. J Solution Chem 2014; 43: 71-82.

Brun M, Lallemand A, Quinson JF, Eyraud C. A new method for the simultaneous determination of the size and the shape of pores: the thermoporometry. Thermochim Acta 1977; 21: 59-88.

Buchwald P. A local glucose-and oxygen concentration-based insulin secretion model for pancreatic islets. Theor Biol Med Model 2011; 8: 1-25.

Buzier R, Charriau A, Corona D, Lenain JF, Fondaneche P, Joussein E, Poulier G, Lissalde S, Mazzella N, Guibaud G. DGT-labile As, $\mathrm{Cd}, \mathrm{Cu}$ and Ni monitoring in freshwater: toward a framework for interpretation of in situ deployment. Environ Pollut 2014; 192: 52-58.

Chance B, Liu H, Kitai T, Zhang Y. Effects of solutes on optical properties of biological materials: models, cells, and tissues. Anal Biochem 1995: 227: 351-362.

Chao TC, Das DB. Numerical simulation of coupled cell motion and nutrient transport in NASA's rotating bioreactor. Chem Eng J 2015; 259: 961-971.

Chaudhuri JB, Davidson MG, Ellis MJ, Jones MD, Wu XJ. Fabrication of honeycomb-structured poly (DL-lactide) and poly[(DL-lactide)co-glycolide] films and their use as scaffolds for osteoblast-like cell culture. Macromol Symp 2008; 272: 52-57.

Choy EM, Evans DF, Cussler EL. A selective membrane for transporting sodium ion against its concentration gradient. J Am Chem Soc 1973; 96: 7085-7090.

Clark AR, Stokes YM, Thompson JG. Estimation of glucose uptake by ovarian follicular cells. Ann Biomed Eng 2011; 39: 2654-2667.

Comiti J, Renaud M. A new model for determining mean structure parameters of fixed beds from pressure drop measurements: application to beds packed with parallelepipedal particles. Chem Eng Sci 1989; 44: 1539-1545.

Couch NP, Wilson RE, Hager EB, Murray JE. Transplantation of cadaver kidneys: experience with 21 cases. Surgery 1966; 59: 183-188.

Crock CA, Rogensues AR, Shan W, Tarabara VV. Polymer nanocomposites with graphene-based hierarchical fillers as materials for multifunctional water treatment membranes. Water Res 2013; 47: 3984-3996.

Daraei P, Madaeni SS, Ghaemi N, Khadivi MA, Astinchap B, Moradian R. Enhancing antifouling capability of PES membrane via mixing with various types of polymer modified multi-walled carbon nanotube. J Membr Sci 2013; 444: 184-191.

Das DB. Multiscale simulation of nutrient transport in hollow fibre membrane bioreactor for growing bone tissue: sub-cellular scale and beyond. Chem Eng Sci 2007; 62: 3627-3639.

Das DB, Jones DR. Multiscale modeling of nutrient transport in bioreactors for growing 3-D bone tissues: subcellular to laboratory scale. Cytotherapy 2006; 8: 34. 
Deans TL, Singh A, Gibson M, Elisseeff JH. Regulating synthetic gene networks in 3D materials. Proc Natl Acad Sci USA 2012; 109: 15217-15222.

DeFriend KA, Wiesner MR, Barron AR. Alumina and aluminate ultrafiltration membranes derived from alumina nanoparticles. J Membr Sci 2003; 224: 11-28.

De Napoli IE, Scaglione S, Giannoni P, Quarto R, Catapano G. Mesenchymal stem cell culture in convection-enhanced hollow fibre membrane bioreactors for bone tissue engineering. J Membr Sci 2011; 379: 341-352.

De Napoli IE, Zanetti EM, Fragomeni G, Giuzio E, Audenino AL, Catapano G. Transport modeling of convection-enhanced hollow fiber membrane bioreactors for therapeutic applications. J Membr Sci 2014; 471: 347-361.

Diban N, Stamatialis D. Polymeric hollow fiber membranes for bioartificial organs and tissue engineering applications. I Chem Technol Biot 2014; 89: 633-643.

Diban N, Ramos-Vivas J, Remuzgo-Martinez S, Ortiz I, Urtiaga A. Poly( $\varepsilon$-caprolactone) films with favourable properties for neural cell growth. Curr Top Med Chem 2014; 14: 2743-2749.

Dietz P, Hansma PK, Inacker O, Lehmann HD, Herrmann KH. Surface pore structures of micro- and ultrafiltration membranes imaged with the atomic force microscope. J Membr Sci 1992; 65: 101-111.

Dollimore D, Heal GR. An improved method for the calculation of pore size distribution from adsorption data. J Appl Chem 1964; 14: 109-114.

Dullien FAL. Prediction of "tortuosity factors" from pore structure data. Am Inst Chem Eng J 1975; 21: 820-822.

Dykhuizen RC, Casey WH. An analysis of solute diffusion in rocks. Geochim Cosmochim Ac 1989; 53: 2797-2805.

Ellis MJ, Chaudhuri JB. Poly(lactic-co-glycolic acid) hollow fibre membranes for use as a tissue engineering scaffold. Biotechnol Bioeng 2007; 96: 177-187.

Ellis MJ, Chaudhuri JB. Human bone derived cell culture on PLGA flat sheet membranes of different lactide:glycolide ratio. Biotechnol Bioeng 2008; 101: 369-377.

Fang L, Liang B, Yang G, Hu Y, Zhu Q, Ye X. Study of glucose biosensor lifetime improvement in $37^{\circ} \mathrm{C}$ serum based on PANI enzyme immobilization and PLGA biodegradable membrane. Biosens Bioelectron 2014; 56: 91-96.

Florczyk SJ, Wang K, Jana S, Wood DL, Sytsma SK, Sham JG, Kievit FM, Zhang M. Porous chitosan-hyaluronic acid scaffolds as a mimic of glioblastoma micronenvironment ECM. Biomaterials 2013; 34: 10143-10150.

Freed LE, Vunjak-Novakovic G. Culture of organized cell communities. Adv Drug Deliver Rev 1998; 33: 15-30.

Freed LE, Vunjak-Novakovic G, Langer R. Cultivation of cell-polymer cartilage implants in bioreactors. J Cell Biochem 1993; 51: 257-264.

Galban CJ, Locke BR. Analysis of cell growth kinetics and substrate diffusion in a polymer scaffold. Biotechnol Bioeng 1999; 65: 121-132.

Gao X, da Costa JCD, Bhatia SK. Understanding the diffusional tortuosity of porous materials: an effective medium theory perspective. Chem Eng Sci 2014; 110: 55-71.

Gardel LS, Serra LA, Reis RL, Gomes ME. Use of perfusion bioreactors and large animal models for long bone tissue engineering. Tissue Eng Part B 2014; 20: 126-146.

Grayson WL, Frhlich M, Yeager K, Bhumiratana S, Chan M, Cannizzaro C, Wan LQ, Liu XS, Guo XE, Vunjak-Novakovic G.
Engineering anatomically shaped human bone grafts. Proc Natl Acad Sci USA 2010; 107: 3299-3304.

Gregg SJ, Sing KSW. Adsorption, surface area and porosity. London: Academic Press, 1982.

Guan S, Zhang XL, Lin XM, Liu TQ, Ma XH, Cui ZF. Chitosan/gelatin porous scaffolds containing hyaluronic acid and heparan sulfate for neural tissue engineering. J Biomat Sci-Polym E 2013; 24: 999-1014.

Guo BL, Ma PX. Synthetic biodegradable functional polymers for tissue engineering: a brief review. Sci China Chem 2014; 57 : 490-500.

Han R. Formation and characterization of (melamine-TMC) based thin film composite NF membranes for improved thermal and chlorine resistances. J Membr Sci 2013; 425-426: 176-181.

Han B, Zhang D, Shao Z, Kong L, Lv S. Preparation and characterization of cellulose acetate/carboxymethyl cellulose acetate blend ultrafiltration membranes. Desalination 2013; 311: 80-89.

Hannoun BJM, Stephanopoulos G. Diffusion coefficients of glucose and ethanol in cell-free and cell-occupied calcium alginate membranes. Biotechnol Bioeng 1986; 28: 829-835.

Hernandez A, Calvo JI, Pradanos P, Tejerina F. Pore size distributions in microporous membranes. A critical analysis of the bubble point extended method. J Membr Sci 1996; 112: 1-12.

Holzwarth JM, Ma PX. 3D nanofibrous scaffolds for tissue engineering. J Mater Chem 2011; 21: 10243-10251.

Hutmacher DW. Scaffold design and fabrication technologies for engineering tissues - state of the art and future perspectives. J Biomater Sci 2001; 12: 107-124.

Jin R, Teixeira LSM, Dijkstra PJ, Zhong Z, van Blitterswijk CA, Karperien M, Feijen J. Enzymatically crosslinked dextrantyramine hydrogels as injectable scaffolds for cartilage tissue engineering. Tissue Eng Part A 2010; 16: 2429-2440.

Khaled A-RA, Vafai K. The role of porous media in modeling flow and heat transfer in biological tissues. Int J Heat Mass Tran 2003; 46: 4989-5003.

Khaled EG, Saleh M, Hindocha S, Griffin M, Khan WS. Tissue engineering for bone production - stem cells, gene therapy and scaffolds. Open Orthop J 2011; 5: 289-295.

Khanafer K, Vafai K. The role of porous media in biomedical engineering as related to magnetic resonance imaging and drug delivery. Heat Mass Transfer 2006; 42: 939-953.

Kim J, der Bruggen BV. The use of nanoparticles in polymeric and ceramic membrane structures: review of manufacturing procedures and performance improvement for water treatment. Environ Pollut 2010; 158: 2335-2349.

Kimelman-Bleich N, Seliktar D, Kallai I, Helm GA, Gazit Z, Gazit $D$, Pelled $G$. The effect of ex vivo dynamic loading on the osteogenic differentiation of genetically engineered mesenchymal stem cell method. J Tissue Eng Regener Med 2011; 5: 384-393.

Koponen A, Kataja M, Timonen J. Tortuous flow in porous media. Phys Rev E 1996; 54: 406-410.

Langer R. Perspectives and challenges in tissue engineering and regenerative medicine. Adv Mater 2009; 21: 3235-3236.

Langer R, Vacanti JP. Tissue engineering. Science 1993; 260: 920-926.

L'Heureux N, Dusserre N, Marini A, Garrido S, de la Fuente L, McAllister T. Technology insight: the evolution of tissue- 
engineered vascular grafts-from research to clinical practice. Nat Clin Pract Cardiovasc Med 2007; 4: 389-395.

Li CKN. The glucose distribution in 91 rat brain multicell tumor spheroids and its effect on cell necrosis. Cancer 1982; 50: 2066-2073.

Li RH, Altreuter DH, Gentile FT. Transport characterization of hydrogel matrices for cell encapsulation. Biotechnol Bioeng 1996; 50: 365-373.

Li X, Zhang G, Xu D, Zhao C, Na H. Morphology study of sulfonated poly (ether ether ketone ketone)s (SPEEKK) membranes: the relationship between morphology and transport properties of SPEEKK membranes. J Power Sources 2007; 165: 701-707.

Li MZ, Li JH, Shao XS, Miao J, Wang JB, Zhang QQ, Xu XP. Grafting zwitterionic brush on the surface of PVDF membrane using physisorbed free radical grafting technique. J Membr Sci 2012; 405-406: 141-148.

Li M, Wang D, Xiao R, Sun G, Zhao Q, Li H. A novel high flux poly(trimethylene terephthalate) nanofiber membrane for microfiltration media. Sep Purif Technol 2013; 116: 199-205.

Li ST, Liu Y, Zhou Q, Lue RF, Song L, Dong SW, Guo P, Branko K. A novel axial-stress bioreactor system combined with a substance exchanger for tissue engineering of 3D constructs. Tissue Eng Part C: Methods 2014; 20: 205-214.

Liabastre AA, Orr C. An evaluation of pore structure by mercury penetration. J Colloid Interf Sci 1978; 64: 1-18.

Liang S, Xu J, Weng L, Dai H, Zhang X, Zhang L. Protein diffusion in agarose hydrogel in situ measured by improved refractive index method. J Control Release 2006; 115: 189-196.

Lin DJ, Chang CL, Chen TC, Cheng LP. Microporous PVDF membrane formation by immersion precipitation from water/TEP/PVDF system. Desalination 2002; 145: 25-29.

Liu H, Beauvoit B, Kimura M, Chance B. Dependence of tissue optical properties on solute-induced changes in refractive index and osmolarity. J Biomed Opt 1996; 1: 200-211.

Liu J, Li P, Li Y, Xie L, Wang S, Wang Z. Preparation of PET threads reinforced PVDF hollow fiber membrane. Desalination 2009; 249: 453-457.

Liu Y, Lim J, Teoh SH. Review: development of clinically relevant scaffolds for vascularised bone tissue engineering. Biotechnol Adv 2013; 31: 688-705.

Lonsdale HK, Merten U, Riley RL. Transport properties of cellulose acetate osmotic membranes. J Appl Polym Sci 1965; 9: 1341-1362.

Madaeni SS, Bakhtiari L. Thermodynamic-based predictions of membrane morphology in water/dimethylsulfoxide/ polyethersulfone systems. Polymer 2012; 53: 4481-4488.

Maier JS, Walker SA, Fantini S, Franceschini MA, Gratton E. Possible correlation between blood glucose concentration and the reduced scattering coefficient of tissues in the near infrared. Opt Lett 1994; 19: 2062-2064.

Mauret E, Renaud M. Transport phenomena in multi-particle systems - I. Limits of applicability of capillary model in high voidage beds-application to fixed beds of fibers and fluidized beds of spheres. Chem Eng Sci 1997; 52: 1807-1817.

McDuff RE, Ellis RA. Determining diffusion coefficients in marine sediments: a laboratory study of the validity of resistivity techniques. Am J Sci 1979; 279: 666-675.

Meneghello G, Parker DJ, Ainsworth BJ, Perera SP, Chaudhuri JB, Ellis MJ, De Bank PA. Fabrication and characterization of poly(lactic-co-glycolic acid)/polyvinyl alcohol blended hollow fibre membranes for tissue engineering applications. J Membr Sci 2009; 344: 55-61.

Mey-Marom A, Katz MG. Measurement of active pore size distribution of microporous membranes - a new approach. J Membr Sci 1986; 27: 119-130.

Mills R. The self-diffusion of chloride ion in aqueous alkali chloride solutions at $25^{\circ}$. J Phys Chem 1957; 61: 1631-1634.

Misener R, Gari MF, Rende M, Velliou E, Panoskaltsis N, Pistikopoulos EN, Mantalaris A. Global superstructure optimisation of red blood cell production in a parallelised hollow fibre bioreactor. Comput Chem Eng 2014; 71: 532-553.

Miyagi A, Nabetani H, Nakajima M. Analysis of transport mechanism of binary organic solvent system through a PDMS-based dense membrane using a regular solution model combined with a solution-diffusion model. Sep Purif Technol 2012; 88: 216-226.

Mohammadi T, Saljoughi E. Effect of production conditions on morphology and permeability of asymmetric cellulose acetate membranes. Desalination 2009; 243: 1-7.

Mohebbi-Kalhori D, Behzadmehr A, Doillon CJ, Hadjizadeh A. Computational modeling of adherent cell growth in a hollow-fiber membrane bioreactor for large-scale 3-D bone tissue engineering. Int J Artif Organs 2012; 15: 250-265.

Nair LS, Laurencin CT. Biodegradable polymers as biomaterials. Prog Polym Sci 2007; 32: 762-798.

Nakao S. Determination of pore size and pore size distribution. J Membr Sci 1994; 96: 131-165.

Nichol JL, Morozowich NL, Allcock HR. Biodegradable alanine and phenylalanine alkyl ester polyphosphazenes as potential ligament and tendon tissue scaffolds. Polym Chem 2013; 4: 600-606.

Nishi M, Matsumoto R, Dong J, Uemura T. Engineered bone tissue associated with vascularization utilizing a rotating wall vessel bioreactor. J Biomed Mater Res A 2013; 101: 421-427.

Omae H, Sun YL, An KN, Amadio PC, Zhao C. Engineered tendon with decellularized xenotendon slices and bone marrow stromal cells: an in vivo animal study. J Tissue Eng Regener Med 2012; 6: 238-244.

Ouerfelli N, Das D, Latrous H, Ammar H, Oliver J. Transport behaviour of the lanthanide ${ }^{152} \mathrm{Eu}(\mathrm{III}),{ }^{153} \mathrm{Gd}(\mathrm{III})$ and ${ }^{170} \mathrm{TM}$ (III) and transplutonium element ${ }^{254} \mathrm{Es}$ (III), ${ }^{244} \mathrm{Cm}$ (III), ${ }^{241} \mathrm{Am}$ (III), ${ }^{249} \mathrm{Cf}$ (III) and ${ }^{249} \mathrm{Bk}$ (III) ions in aqueous solutions at $298 \mathrm{~K}$. J Radioanal Nucl Ch 2014; 300: 51-55.

Page H, Flood P, Reynaud EG. Three-dimensional tissue cultures: current trends and beyond. Cell Tissue Res 2013; 352: 123-131.

Palacio L, Pradanos P, Calvo Jl, Hernandez A. Porosity measurements by a gas penetration method and other techniques applied to membrane characterization. Thin Solid Films 1999; 348: 22-29.

Papenburg BJ, Vogelaar L, Bolhuis-Versteeg LAM, Lammertink RGH, Stamatialis D, Wessling M. One-step fabrication of porous micropatterned scaffolds to control cell behavior. Biomaterials 2007; 28: 1998-2009.

Patrick CW, Mikos AG, McIntire LV. Prospects of tissue engineering, Frontiers in Tissue Engineering. Elsevier Science Ltd: Oxford, 1998; 3-11.

Pearson NC, Shipley RJ, Waters SL, Oliver JM. Multiphase modelling of the influence of fluid flow and chemical concentration on tissue growth in a hollow fibre membrane bioreactor. Math Med Biol 2013; 31: 393-430. 
Petersen EE. Diffusion in a pore of varying cross section. Am Inst Chem Eng J 1958; 4: 343-345.

Pleitez MA, Hertzberg O, Bauer A, Seeger M, Lieblein T, Lilienfeld-Toal HV, Mantele W. Photothermal deflectometry enhanced by total internal reflection enables non-invasive glucose monitoring in human epidermis. Analyst 2015; 140 : 483-488.

Podichetty JT, Bhaskar PR, Singarapu K, Madihally SV. Multiple approaches to predicting oxygen and glucose consumptions by HepG2 cells on porous scaffolds in an axial-flow bioreactor. Biotechnol Bioeng 2014; 112: 393-404.

Provin C, Takano K, Sakai Y, Fujii T, Shirakashi R. A method for the design of 3D scaffolds for high-density cell attachment and determination of optimum perfusion culture conditions. J Biomech 2008; 41: 1436-1449.

Rahimpour A, Jahanshahi M, Khalili S, Mollahosseini A, Zirepour A, Rajaeian B. Novel functionalized carbon nanotubes for improving the surface properties and performance of polyethersulfone (PES) membrane. Desalination 2012; 286: 99-107.

Regional data of the US Scientific Registry for transplant recipients, donor and wait-listed patients from 2000 to 2012, United Network for Organ Sharing: Richmond, Virginia, www.unos.org.

Riedel C, Spohr R. Transmission properties of nuclear track filters. J Membr Sci 1980; 7: 225-234.

Ribeiro ACF, Ortona O, Simoes SMN, Santos CIAV, Prazeres PMRA, Valente AJM, Lobo VMM, Burrows HD. Binary mutual diffusion coefficients of aqueous solutions of sucrose, lactose, glucose and fructose in the temperature range from (298.15 to 328.15) K. J Chem Eng Data 2006; 51: 1836-1840.

Ribeiro ACF, Barros MCF, Verissimo LMP, Lobo VMM, Valente AJM. Binary diffusion coefficients for aqueous solutions of L-aspartic acid and its respective monosodium salt. J Solution Chem 2014; 43: 83-92.

Rong Z, Cheema U, Vadgama P. Needle enzyme electrode based glucose diffusive transport measurement in a collagen gel and validation of a simulation model. Analyst 2006; 131 : 816-821.

Sachlos E, Czernuszka JT. Making tissue engineering scaffolds work. Review on the application of solid freeform fabrication technology to the production of tissue engineering scaffolds. Eur Cell Mater 2003; 5: 29-40.

Sadighi S, Bahmani M, Mohadecy SRS. Effect of pore size distribution and temperature on the catalyst tortuosity. Chem Eng Res Bull 2013; 16: 61-72.

Schulz RM, Wustneck N, van Donkelaar CC, Shelton JC, Bader A. Development and validation of a novel bioreactor system for load- and perfusion-controlled tissue engineering of chondrocyte-constructs. Biotechnol Bioeng 2008; 101: 714-728.

Setiawan L, Wang R, Li K, Fane AG. Fabrication of novel poly(amide-imide) forward osmosis hollow fiber membranes with a positively charged nanofiltration-like selective layer. J Membr Sci 2011; 369: 196-205.

Shanbhag S, Lee JW, Kotov N. Diffusion in three-dimensionally ordered scaffolds with inverted colloidal crystal geometry. Biomaterials 2005; 26: 5581-5585.

Sharma RR, Chellam S. Temperature effects on the morphology of porous thin film composite nanofiltration membranes. Environ Sci Technol 2005; 39: 5022-5030.
Shen L, Chen Z. Critical review of the impact of tortuosity on diffusion. Chem Eng Sci 2007; 62: 3748-3755.

Sherwood TK, Brian PLT, Fisher RE. Desalination by reverse osmosis. Ind Eng Chem Fundam 1967; 6: 2-12.

Shi C, Wright GJ, Ex-Lubeskie CL, Bradshaw AD, Yao H. Relationship between anisotropic diffusion properties and tissue morphology in porcine TMJ disc. Osteoarthr Cartilage 2013; 21: 625-633.

Soraruf D, Roosen-Runge F, Grimaldo M, Zanini F, Schweins R, Seydel T, Zhang F, Roth R, Oettel M, Schreiber F. Protein cluster formation in aqueous solution in the presence of multivalent metal ions - a light scattering study. Roy Soc Chem 2014; 10 : 894-902.

Suhaimi H, Wang S, Das DB. Glucose diffusivity in cell culture medium. Chem Eng J 2015a; 269: 323-327.

Suhaimi H, Wang S, Thornton T, Das DB. On glucose diffusivity of tissue engineering membranes and scaffolds. Chem Eng Sci 2015b; 126: 244-256.

Sukitpaneenit P, Chung TS. Molecular elucidation of morphology and mechanical properties of PVDF hollow fiber membranes from aspects of phase inversion, crystallization and rheology. J Membr Sci 2009; 340: 192-205.

Sweerts JP, Kelly CA, Rudd JW, Hesslein R, Cappenberg TE. Similarity of whole-sediment molecular diffusion coefficients in freshwater sediments of low and high porosity. Limnol Oceanogr 1991; 36: 335-342.

Tabata Y. Positioning of tissue engineering in regenerative medicine. Inflamm Regen 2014; 34: 1-3.

Tham MK, Walker Jr RD, Modell JH. Diffusion coefficients of $\mathrm{O}_{2}, \mathrm{~N}_{2}$ and $\mathrm{CO}_{2}$ in fluorinated ethers. J Chem Eng Data 1973; 18: 411-412.

Travascio F, Jackson AR, Brown MD, Gu WY. Relationship between solute transport properties and tissue morphology in human annulus fibrosus. J Orthop Res 2009; 27: 1625-1630.

Trichet AAP, Foster J, Omori NE, James D, Dolan PR, Hughes GM, Vallance C, Smith JM. Open-access optical microcavities for lab-on-a-chip refractive index sensing. Lab Chip 2014; 14 : 4244-4249.

Tsuru T, Toyosada T, Yoshioka T, Asaeda M. Photocatalytic reactions in a filtration system through porous titanium dioxide membranes. J Chem Eng Jpn 2001; 34: 844-847.

Tuchin VV, Maksimova IL, Zimnyakov DA, Kon IL, Mavlutov AH, Mishin AA. Light propagation in tissues with controlled optical properties. J Biomed Opt 1997; 2: 401-417.

Turhan M, Desai MA, Vadgama P, Mutlu M. Estimation of liquid diffusivities of biosolutes by using diaphragm cell method with defined pore characteristics. Biotechnol Tech 1995; 9: 413-416.

Uehara S, Hanasaki I, Arai Y, Nagai T, Kawano S. Statistical characterisation of single-stranded DNA motion near glass surface beyond diffusion coefficient. Micro Nano Lett 2014; 9: 257-260.

Ullah H, Ahmed E, Ikram M. Monitoring of glucose levels in mouse blood with noninvasive optical methods. Laser Phys 2014; 24: 1-8.

Van Cappellen P, Gaillard JF. Biogeochemical dynamics in aquatic systems. Rev Mineral 1996; 34: 335-376.

Van Winkle AP, Gates ID, Kallos MS. Mass transfer limitations in embryoid bodies during human embryonic stem cell differentiation. Cells Tissues Organs 2012; 196: 34-47.

Vargas G, Chan KF, Thomsen SL, Welch AJ. Use of osmotically active agents to alter optical properties of tissue: effects on the 
detected fluorescence signal measured through skin. Laser Surg Med 2001; 29: 213-220.

Vindigni V, Abatangelo G, Bassetto F. New developments in tissue engineering of microvascular prostheses (Chapter 21), Biomaterials Science and Engineering. Croatia: InTech publisher, 2011.

Wang RK. Modelling optical properties of soft tissue by fractal distribution of scatterers. J Mod Optic 2000; 47: 103-120.

Wang J, Musameh M. Enzyme-dispersed carbon-nanotube electrodes: a needle microsensor for monitoring glucose. Roy Soc Chem 2003; 128: 1382-1385.

Wang S, Liu W, Han B, Yang L. Study on a hydroxypropyl chitosangelatin based scaffold for corneal stroma tissue engineering. Appl Surf Sci 2009; 255: 8701-8705.

Washburn EW. The dynamics of capillary flow. Phys Rev 1921; 17 : 273-283.

Wendt RP, Shamim M. Isothermal diffusion in the system water-magnesium chloride-sodium chloride as studied with the rotating diaphragm cell. J Phys Chem 1970; 74: 2770-2783.

Weng L, Liang S, Zhang L, Zhang X, Xu J. Transport of glucose and poly(ethylene glycol)s in agarose gels studies by the refractive index method. Macromolecules 2005; 38: 5236-5242.

Wilke CR, Chang P. Correlation of diffusion coefficients in dilute solutions. Am Inst Chem Eng J 1955; 1: 264-270.

Wung N, Acott SM, Tosh D, Ellis MJ. Hollow fibre membrane bioreactors for tissue engineering applications. Biotechnol Lett 2014; 36: 2357-2366.

Xue CH, Wang D, Xiang B, Chiou BS, Sun G. Controlled and high throughput fabrication of poly(trimethylene terephthalate) nanofibers via melt extrusion of immiscible blends. Mater Chem Phys 2010; 124: 48-51.

Yang S, Leong KF, Du Z, Chua CK. The design of scaffolds for use in tissue engineering. Part I. Traditional factors. Tissue Eng 2001; 7: 679-689.
Yao L, Cheng H, Luo Q, Zhang W, Zeng S, Tuchin VV. Control of rabbit dura mater optical properties with osmotical liquids, Society of Photo-Optical Instrumentation Engineers Proceedings 4536, International Workshop on Photonics and Imaging in Biology and Medicine, 2002; 4536: 147-152.

Yaroshchuk A, Martinez-Llado X, Llenas L, Rovira M, de Pablo J. Solution-diffusion-film model for the description of pressure-driven trans-membrane transfer of electrolyte mixtures: one dominant salt and trace ions. J Membr Sci 2011; 368: 192-201.

Ye H, Das DB, Triffitt JT, Cui Z. Modelling nutrient transport in hollow fibre membrane bioreactors for growing three-dimensional bone tissue. J Membr Sci 2006; 272: 169-178.

Yoo EH, Lee SY. Glucose biosensors: an overview of use in clinical practice. Sensors 2010; 10: 4558-4576.

Zhang Y, Wang R, Yi S, Setiawan L, Hu X, Fane AG. Novel chemical surface modification to enhance hydrophobicity of polyamide-imide (PAI) hollow fiber membranes. J Membr Sci 2011; 380: 241-250.

Zhang Y, Wei H, Yang H, He Y, Wu G, Xie S, Zhu Z, He R. Noninvasive blood glucose monitoring during oral intake of different sugars with optical coherence tomography in human subjects. J Biophotonics 2013a; 6: 699-707.

Zhang X, Xiao C, Hu X, Bai Q. Preparation and properties of homogeneous-reinforced polyvinylidene fluoride hollow fiber membrane. Appl Surf Sci 2013b; 264: 801-810.

Zhao S, Wang Z, Wei X, Zhao B, Wang J, Yang S, Wang S. Performance improvement of polysulfone ultrafiltration membrane using PANiEB as both pore forming agent and hydrophilic modifier. J Membr Sci 2011; 385-386: 252-262.

Zhu W, Wang M, Fu Y, Castro NJ, Fu SW, Zhang LJ. Engineering a biomimetic three-dimensional nanostructured bone model for breast cancer bone metastasis study. Acta Biomater 2015; 14 : 164-174. 